
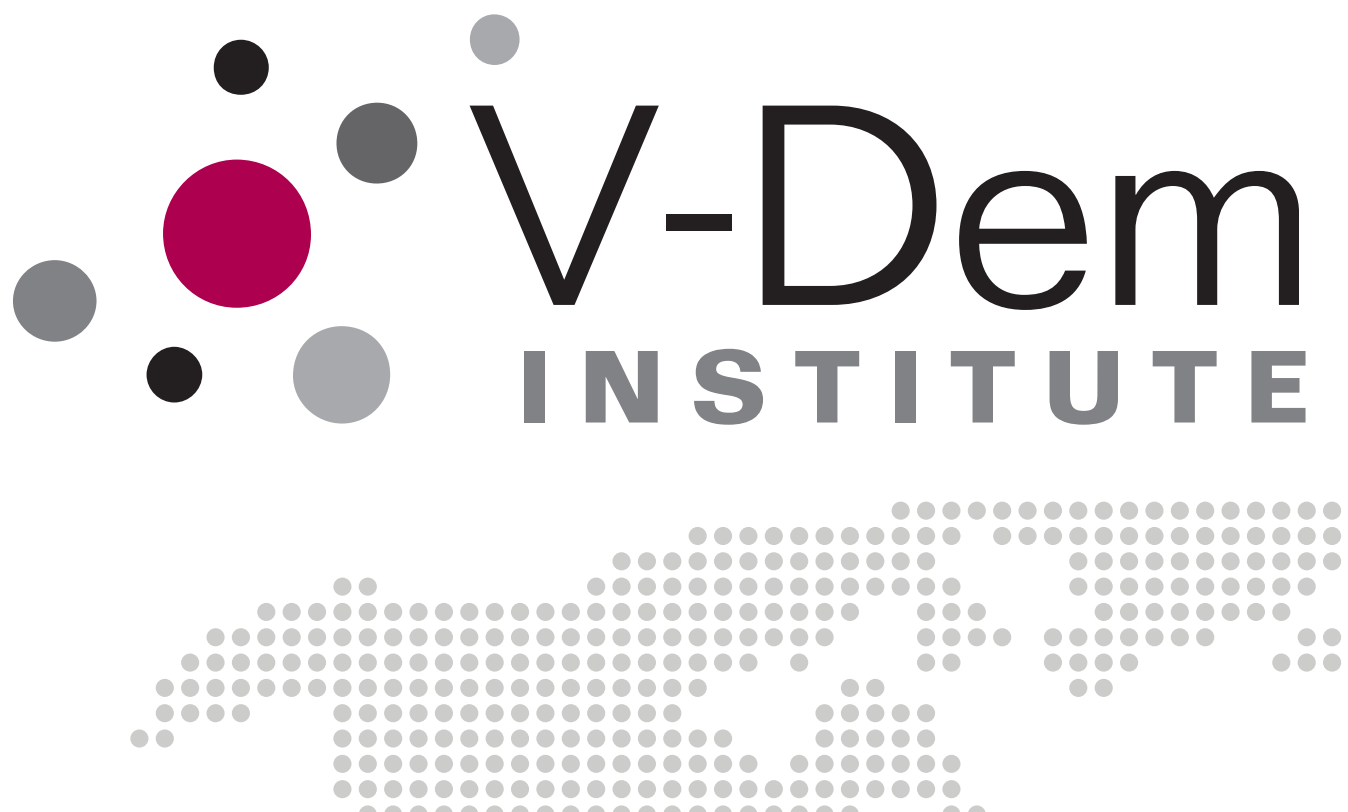

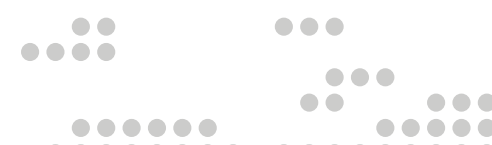

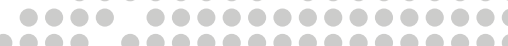
1000

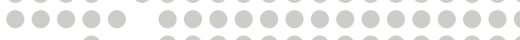

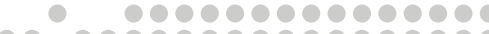
00 מ

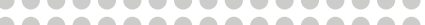
rober

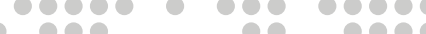

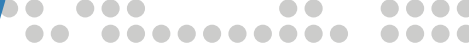

Does Democracy or Good Governance Enhance Health? New Empirical Evidence 1900-2012

Yi-ting Wang Valeriya Mechkova Frida Andersson
0000000000

300000000

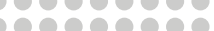
100

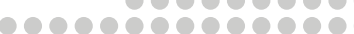

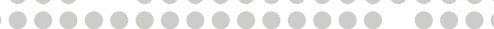
10000000000 00000 0000000000000000

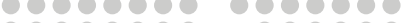
1000000000000 100000000000000 000000

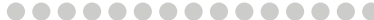

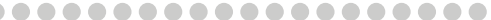

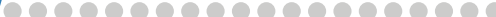

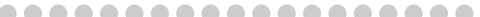
000000000000 00000000000000 000000000000 00000000000 0000000000 0

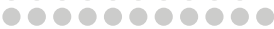

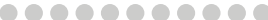
06000009000

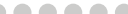

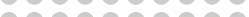

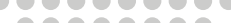
10000000 10000000

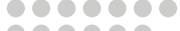

000000 000

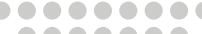
resereser 100000 10000 000 1000 00 100 Oe 10

September 2015

\section{Working Paper}

SERIES 2015:11

THE VARIETIES OF DEMOCRACY INSTITUTE
UNIVERSITY OF GOTHENBURG DEPT OF POLITICAL SCIENCE 
Varieties of Democracy (V-Dem) is a new approach to the conceptualization and measurement of democracy. It is co-hosted by the University of Gothenburg and University of Notre Dame. With a V-Dem Institute at University of Gothenburg that comprises almost ten staff members, and a project team across the world with four Principal Investigators, fifteen Project Managers, 30+ Regional Managers, 170 Country Coordinators, Research Assistants, and 2,500 Country Experts, the V-Dem project is one of the largest-ever social science research-oriented data collection programs.

Please address comments and/or queries for information to:

V-Dem Institute

Department of Political Science

University of Gothenburg

Sprängkullsgatan 19, PO Box 711

SE 40530 Gothenburg

Sweden

E-mail: contact@v-dem.net

V-Dem Working Papers are available in electronic format at www.v-dem.net.

Copyright (C) 2015 by authors. All rights reserved. 


\title{
Does Democracy or Good Governance Enhance Health? New Empirical Evidence 1900-2012*
}

\author{
Yi-ting Wang \\ Assistant Professor \\ National Cheng Kung University \\ Valeriya Mechkova \\ Analyst and Data Operations Manager, V-Dem Institute \\ University of Gothenburg \\ Frida Andersson \\ Analyst and Data Operations Officer, V-Dem Institute \\ University of Gothenburg
}

* This research project was supported by Riksbankens Jubileumsfond, Grant M13-0559:1, PI: Staffan I. Lindberg, VDem Institute, University of Gothenburg, Sweden; by Swedish Research Council, 2013.0166, PI: Staffan I. Lindberg, V-Dem Institute, University of Gothenburg, Sweden and Jan Teorell, Department of Political Science, Lund University, Sweden; by Knut and Alice Wallenberg Foundation to Wallenberg Academy Fellow Staffan I. Lindberg, V-Dem Institute, University of Gothenburg, Sweden; by University of Gothenburg, Grant E 2013/43. 


\begin{abstract}
It has been long debated whether regime types have impacts on human development. More specifically, compared to authoritarianism, are democracies more likely to provide public goods, including infrastructure that improve food provision and health care, and thus enhance health? Some studies support an optimistic view, and argue that with the accountability mechanisms of democratic elections, democracy is helpful in improving health. Some recent studies challenge the optimistic argument, and point out good governance, rather than regime types, as a more crucial determinant of human development. Using a newly collected dataset that covers 173 countries over the years 1900-2012 and contains more nuanced measures than commonly used, we intend to disentangle the debate. The results suggest that across models with various specifications, regime types have more consistent effects than quality of government on health outcomes throughout the entire period. Furthermore, we find that the mixed results of extant studies are due to that 1) the commonly used governance indicators are measured only for the recent decades, and the sample does not reflect the entire range of variation; 2) the positive effects of democracy are especially salient once the level of democracy has achieved certain threshold; 3) the positive effects of democracy are especially stable when both vertical and horizontal accountability mechanisms are improved.
\end{abstract}




\section{Introduction}

Following the cold war, democracy and human rights became dominating principles of a new global order and democracy promotion as a foreign policy goal has been increasingly accepted within the international community (Guilhot 2005). Although an extensive literature on democracy and democratization has emerged, the questions of whether and to what extent democracy can improve the lives of ordinary citizens are still up for discussion (Besley and Kudamatsu 2006).

Lately, a debate has emerged within political science research on the relationship between regime types and human welfare. On the one hand, many scholars have provided theoretical arguments and empirical evidence supporting a positive relationship between democracy and human development (Vollmer and Ziegler 2009, Deacon and Saha 2005, Antonis et al. 2009, Biser and Edwards 2012, Franco, Álvarez-Dardet and Ruiz 2004, Klomp and de Haan 2009). On the other hand, this view has been increasingly scrutinized by studies that challenge the robustness of the empirical analyses (Ross 2006) and more fundamentally the causality linking the two aspects (Gauri and Khaleghian 2002, McGuire 2004, Shandra et al. 2004, Norris 2012, Rothstein 2014). A field of research questioning the democracy argument promotes a shift of focus from regime type to good governance and the quality of government as a crucial determinant of human development and public goods provision (Diamond 2007, Sacks and Levi 2007, Holmberg and Rothstein 2009 and 2010, Rothstein 2011, Lewis 2006).

Utilizing a newly collected dataset that covers 173 countries over the years 1900-2012 and contains more nuanced measures for both democracy and good governance, we intend to disentangle the debate and compare the impacts of different aspects of democracy and governance on population health. Extant indices of good governance provide data generally for only the most recent decades which may result in biased inferences. With regard to the measures of regime type, existing studies almost exclusively rely on measures provided by Freedom House or Polity IV, which tend to treat democracy as one-dimensional phenomena. Using indicators that more concretely capture the democratic accountability mechanisms and distinguish between vertical and horizontal accountability mechanisms, we further examine the conditions under which democracy is more likely to improve health outcomes.

Our analyses suggest that regime type has more consistent impact on health outcomes than the quality of government. The mixed results identified in previous research are partly due to incomplete samples of examined cases that do not reflect a rich range of variation across countries and years. During the most recent two decades, the variations of the governance indicators across non-democracies are quite limited. In addition, we find that the positive impacts 
of democracy are especially salient when both vertical and horizontal accountability mechanisms are present. Furthermore, the positive impact of democracy on health outcomes is clearer if the threshold effect of democracy is also taken into account. That is, after the transitional period of democratization, population health more significantly improves as democracy matures.

On a policy level, this paper contributes with insights on what factors might have positive effects on health in order to get closer to development goals, as defined for example in the Millennium Development Goals and in the post-2015 development agenda. It could be of value for the development assistance community to get further insights on if democracy promotion is truly motivated or if there is a reason to shift focus to other aspects of governance. If more states are to succeed in improving human well-being and population health in this case, a more precise understanding and knowledge of which aspects of governance and democracy that matters is of crucial importance.

In the following section, we discuss theories linking regime type, quality of governance, and public goods provision. Next, we describe data and measures utilized in this paper. After presenting the empirical results, we discuss the limitations and future extensions of the study.

\section{Theoretical Discussion: Democracy, Good Governance, and Health Outcomes}

Although the worldwide spread of democracy has instigated a substantial field of literature, some critics argue that the main purpose of this research so far has been to examine the causes and barriers of the development of representative democracy in different states, while the question of how democracies actually perform and influence the lives of their citizens to a large extent has been left unanswered (Rothstein 2011). While many studies emphasize that democracies perform better than non-democratic states in terms of producing human welfare and providing public goods for their citizens (Vollmer and Ziegler 2009, Deacon and Saha 2005, Antonis et al. 2009, Biser and Edwards 2012, Franco, Álvarez-Dardet and Ruiz 2004, Klomp and de Haan 2009), this claim is now being increasingly questioned based on the notion that many democracies fail in these aspects (Ross 2006, Holmberg and Rothstein 2010, Rothstein 2011, Diamond 2007). As emphasized by Besley and Kudamatsu (2006:313), in spite of the substantial increase of democratic states around the world, the question of how regime type affects the well-being of the world population is still open to debate. 


\subsection{The Effects of Regime Type}

A number of scholars have identified that democracy promotes human welfare and the provision of public goods in terms of infrastructure, water, public sanitation and public schooling (Deacon and Saha 2005, Antonis et al. 2009, Biser and Edwards 2012), whereas some has looked more specifically on health outcomes. For example, Franco, Álvarez-Dardet and Ruiz (2004) find that democracy shows an independent positive impact on life expectancy, maternal mortality and infant mortality, taking a country's wealth, level of inequality and size of the public sector into account. Similarly, a study by Klomp and de Haan (2009) suggests that there is indeed a positive relationship between democracy and individual health. With a focus on sub-Saharan Africa, Kudamatsu (2012) points out that infant mortality rates fall after democratization in the postCold War period. Furthermore, Besley and Kundamatsu (2006) argue that health policy interventions are superior in democratic states.

Scholars have pointed out several mechanisms through which democracies are more likely to provide public goods and improve human development. The various mechanisms can be classified into three categories: representation, accountability and selection (Besley and Kudamatsu 2006:313-314, Harding and Wantchekon 2010:14-18), all of which rest on competitive elections of democracies.

The representation mechanism relates to preferences represented by those who control political office. Acemoglu and Robinson (2005) refer to democracies as dictatorships of the poor and middle class citizens and autocracies as dictatorships of the rich. According to this argument, human welfare will increase if it is of importance to the dominating groups of the democracy, compared to the groups dominating in an autocracy. Through competitive elections, the redistributive scheme in a democratic regime is more likely to reflect the preference of the median voter, belonging to the middle and lower class (Vollmer and Ziegler 2009). One can expect greater provision of public goods in a democracy than in an autocracy, since the people represented by the power holders of a democratic system have higher preferences and demands for redistribution of resources and public services. In authoritarian regimes, however, redistribution incentives are missing and fewer public goods are provided (Besley and Kudamatsu 2006:313-314, Harding and Wantchekon 2010:14-18).

The accountability argument is based on that in democracies, citizens have the ability to hold politicians accountable through elections. As a result, decision-makers feel obligated to provide a wider range of the population with public goods in order to meet the expectations of the voters and stay in power in the next elections, while power holders in autocracies are 
accountable only to a narrow group of people (Besley and Kudamatsu 2006:313-314,Harding and Wantchekon 2010:14-18).

The selection argument emphasizes the process of appointing political leaders and government officials as an important difference between democratic and autocratic states. In democracies, the mechanisms to select credible and competent politicians are stronger than in autocracies. Hence, health intervention policies in democracies are supported and implemented by knowledgeable and impartial officials, which leads to improved health outcomes, unlike in autocratic states where public servants might not be selected on a merit-base (Besley and Kudamatsu 2006:313-314, Harding and Wantchekon 2010:14-18).

\subsection{The Debate}

While many theoretical arguments and empirical analyses suggest that democracy has positive effects on human welfare, some recent studies criticize this optimistic view. Some of the criticisms focus on the quality of empirical analyses conducted in previous works, while others more fundamentally question the causal relationship between regime types and public goods provision.

The empirical evidence supporting the optimistic view has been criticized as scarce, based on biased samples and open to scientific debate (Ross 2006). In addition, other studies find only a weak, non-existent or even negative relationship between democracy and different aspects of health (Gauri and Khaleghian 2002, McGuire 2004, Ross 2006, Shandra et al. 2004, Rothstein 2011). According to Ross (2006:860-861), past quantitative cross-national studies confirming the optimistic view have been flawed by not taking into account global health trends and country-specific effects, which complicate the possibility to trace the correct factors driving positive health developments. Another issue brought forward is the limited and biased sample of countries included in many of the studies: when data to a much larger extent is available for democratic states but missing for non-democracies, the results are based on a smaller skewed sample of countries. In many studies, nondemocratic states with good economic social development have been excluded from the analysis, resulting in a false impression that democracies perform better than nondemocracies.

Once these flaws are corrected, the study carried out by Ross (2006:868-871) suggests that democracy has little or no effect on health indicators such as infant and child mortality. Similarly, Shandra et al. (2004) discover that the level of democracy does not have a significant effect on infant mortality rate. Gauri and Khaleghian (2002) find that immunization coverage rates are actually lower in democracies than autocracies across developing countries. Norris (2012) investigates the effect of liberal democracy on a number of aspects of human well-being, 
captured by the Millennium Development Goals, and her analysis shows no positive impact on either longevity nor child mortality. Overall, based on the uneven track records of democracies' ability to ensure human welfare, many argue that representative democracy does not seem to be a safe cure against under-provision of welfare (Holmberg and Rothstein 2010, Ross 2006, Diamond 2007).

Another thread of research questions the causal relationship between democracy and public goods provision, and points out good governance, rather than regime type, as the main determinant of desirable social outcomes. An extensive literature on the importance of good governance has emerged, paying attention to its impacts on various aspects of social wellbeing (Diamond 2007, Sacks and Levi 2007, Holmberg and Rothstein 2009 and 2010, Rothstein 2011, Lewis 2006, Norris 2012).

According to Diamond (2007:119), democracy today is haunted by a ghost. That is, bad governance in the form of corruption, favoritism, patronage and abuse of power, which weakens several mechanisms through which democratic officials have more incentives to improve population health. Rothstein and Holmberg (2010) offer an overview of the relation between variables that measure the quality of government, such as rule of law, control of corruption and government effectiveness, and a number of standard measures of population health. The overall finding is that different aspects of quality of government are positively related to standard measures of population health such as life expectancy at birth and infant mortality.

Another group of scholars point out the importance of the "age" of democracy and argue that the accountability mechanism works better in older democracies. Keefer and Vlaicu (2004:25-27) state that politicians in young democracies tend to fail to make credible promises to their voters, and thus are likely to engage in direct and contingent exchanges rather than provide public goods once in office. Political leaders in older democracies, on the other hand, have a greater opportunity to create credible policy reputations among a wider range of voters and are able to offer a more extensive provision of public goods. The argument is supported also by empirical evidence (Keefer 2005). Similarly, Gerring et al. (2012) argue that the relationship between democracy and human development is a time-dependent phenomenon. According to the authors, there is only slight evidence for a positive relationship between democracy and infant mortality and over the past century, it is the stock of democracy that in fact affects infant mortality. 


\subsection{Hypothesis}

As evident from the theoretical discussion, whether and the conditions under which democracy improves population health is still under debate. In this paper, we intend to test these arguments more thoroughly, with a newly collected dataset that covers most sovereign countries from 1900 to 2012 for indicators of regime type and governance quality. As Ross (2006) points out, incomplete samples may result in biased inferences. Previous works that compare the effects of regime type and governance are limited by extant governance indices measured only for the recent decades. In the empirical analyses, we incorporate controls that capture global health trends and country-specific effects, and apply various model specifications for imputed data sets to ensure the robustness of the tests.

More importantly, when comparing the effects of democracy and quality of government, we focus on specific accountability mechanisms of democracy. The skepticism towards democracy promotion and the argument that democracy promotes various desirable social outcomes has raised an awareness of the need to discuss different dimensions of democracy. However, in large parts of the literature on the effects of democracy, as well as the critique towards it, focus is merely on a few aspects of democracy. In addition, extant studies almost exclusively rely on measures provided by Freedom House, Polity IV and Economist Intelligence Unit, which tend to treat various aspects of democracy as one-dimensional phenomena. Although these studies in theory elaborate on particular dimensions and mechanisms of democracy, such as elections, representations, or checks and balances, in practice in their empirical analysis they tend to rely on one-dimensional measures that combine different features of democracies.

We argue that vertical accountability (competitive elections) and horizontal accountability (legislative constraints on the executive) mechanisms of democracy are both important to improve population health. The distinction between them is commonly used in the literature to refer to different types of accountability mechanisms regarding the spatial direction of the accountability relationships (Schedler 1999, Lindberg 2013). Accountability in this context is defined as the main instrument through which both public institutions and individuals are subject to monitoring and control by citizens as well as other public institutions (World Bank Institute 2005).

Vertical accountability allows citizens to hold governments and politicians directly accountable through free and fair elections, along with freedoms of expression, free media, and freedom of association (O’Donnell 1998). The presence of these factors combined enables citizens to voice and demand their preferences to politicians and public institutions. Through the 
mechanism of regular competitive elections citizen can freely articulate their preferences for policies. Holding regular elections does not automatically mean that these elections correspond to the will of the citizens, as more than half of the current elections in the world violate the democratic principles of basic freedom and fairness, and the respect for human rights (Diamond 2002, Hafner-Burton et al 2013:152, Lindberg 2006, 2009, Schedler 2002). Hence, factors such as suffrage, freedom of association, and the level of "cleanness" of elections in terms of absence of fraud or systematic irregularities need to be taken into account to assess the effect of electoral democracy. In addition, since elections occur only periodically, the ability of citizens to freely associate in political parties and non-governmental organizations are crucial elements in order to secure vertical accountability also in the period between elections.

Horizontal accountability is achieved when there is oversight between different state institutions in terms of checks and balances, preventing abuses of political power. When, for example, the legislature engages in executive oversight or a constitutional court reviews acts adopted by the legislature, this is a form of accountability that runs horizontally 'among equals' (O’Donnell,1998, Lindberg 2013). A focus on legislative control is based on the idea that legislatures are the primary national-level agency through which popular preferences are institutionally represented, laws are passed, and restraint can be imposed on the executive. As Keefer and Vlaicu (2004) point out, politicians in young democracies are less able to make credible policy commitments. We argue that legislatures can serve as a credible constraint on government's behavior of only transferring benefits to narrow groups of voters. With the capability of questioning, investigating, and exercising oversight over the executive, legislatures are more likely to counterbalance the tendency of delivering clientelistic benefits that are contingent on the support of the governing party. That is, with the mechanism of horizontal accountability, policy commitments offered by politicians are more likely to be credible, and thus politicians have more incentives to provide large-scale benefits. Based on these arguments, we plan to test the following opposing hypotheses:

\section{H1.1: Democratic accountability mechanism has a stronger impact on population health than quality of} government.

\section{H1.2: Quality of government has a stronger impact on population health than regime type.}

Furthermore, we hypothesize that vertical and horizontal accountability mechanisms work as complements. Competitive elections or legislative constraints separately are not enough to ensure improved health outcomes. Executive and legislative politicians have incentives to represent citizens' preferences and deliver goods only when they are faced with the uncertainty of re-election. Legislative control is required so that government officials selected through 
competitive elections are more likely to make credible commitments of providing public goods. That is, the effects of these two accountability mechanisms are more salient if the other mechanism is also present. Based on these arguments, a hypothesis on the joint effect of vertical and horizontal accountability mechanisms is proposed:

H2: The impact of democracy on population health is more salient if both vertical and horizontal accountability mechanisms are strengthened.

Related to the joint effect of different dimensions of democracy, we also expect that at the early stage of democratization, increased political rights do not necessarily lead to the improvement of population health. Transitional societies, although allowing more political competition than close autocracies, still lack democratic accountability mechanisms. That is, democracies without well-functioned accountability mechanisms are less able to achieve significant improvement in population health. Only when politicians and citizens have recognized that winning competitive elections is the only way to political power, and providing public goods to a larger scale of population is helpful in attracting votes, accountability mechanisms function better. In other words, there is a threshold effect of democracy on health outcome. The positive impact of democracy on population health is especially significant after the early stage of democratic transition. Based on this expectation, a third hypothesis is proposed:

H3: There is a threshold effect of democracy on population health. The positive impact of democracy is more salient as democracy matures.

\section{Data and Measures}

To explore the effects of regime types and quality of government on health outcomes, we utilize mainly the new data produced by the Varieties of Democracy (V-Dem) project (dataset version 4.3) ${ }^{1}$. The V-Dem dataset is currently the largest dataset on democracy, collecting data for 173 polities in the world for 400+ indicators from 1900 to 2012 (for 60 countries also for 2013-2014). The project distinguishes among seven main principles of democracy (electoral, liberal, deliberative, majoritarian, consensual, egalitarian, and participatory) that are disaggregated into around fifty constituent component parts, each measured by several detailed and concrete indicators. The disaggregated nature of the V-Dem data allows the selection of indicators that more accurately capture the theoretical concepts motivated in this paper.

\footnotetext{
${ }^{1}$ See https://v-dem.net for more information about the project and the codebook.
} 
Different from existing datasets, which usually rely on a small group of experts who rate all countries or ask each expert to code one single unit, V-Dem project has invited over 2,500 local and cross-national experts to provide judgments on various indicators about democracy (Coppedge et al. 2011, 2015). Thus, the dataset is compiled by gathering factual information from existing data sources, and by expert coding for questions that require evaluation. Experts' ratings are aggregated through a Bayesian item response theory model (Pemstein et al. 2015). The model takes into account the possibilities that experts may make mistakes and have different scales in mind when providing judgments. In addition, bridging-coders, experts who coded multiple countries, are recruited to calibrate the scales of estimates cross-nationally. Finally, the project is completely transparent regarding coding procedures, the measurement model that processes the country experts' data, the aggregation decisions of the composite indicators, and thus for possible sources of measurement error.

\subsection{Independent Variables: Democracy and Quality of Government}

To test whether the mechanisms that require politicians to represent and be accountable to their citizens are helpful for population health, we utilize two measures that capture vertical and horizontal accountability. For the former, we rely on the electoral accountability index from the VDem dataset that fits quite accurately the conceptualization used in this paper for vertical accountability. In the V-Dem conceptual scheme the electoral principle of democracy is defined as selecting responsive and accountable leaders to citizens through the mechanism of competitive meaningful elections as captured by Dahl's conceptualization for "polyarchy" (1989). This is assumed to be achieved when elections are free and fair; the executive is selected (directly or indirectly) through elections; suffrage is extensive; and, finally, political and civil society organizations can operate freely. To capture this definition, the electoral accountability index combines indicators on the level of suffrage, freedom to join political and civil society organizations, whether elections are clean and without systematic irregularities, and whether the chief executive is selected through elections ${ }^{2}$.

To capture the concept of horizontal accountability as defined above, we utilize the legislative constraints on the executive index, which focuses on the extent to which the national legislature/parliament are capable of questioning, investigating, and exercising oversight over the executive. This index is formed by taking the point estimates from a Bayesian factor analysis

\footnotetext{
${ }^{2}$ For detailed information on the aggregation formula and the exact question formulation of the indicators going into the index, see the Appendix, Table A.1 and A.2. It has to be noted that while expert survey questionnaire provides ordinal raw scores, the measurement model produces interval-level estimates of latent traits with roughly 0 as the average and 1 as the standard deviation when aggregating experts' ratings.
} 
model of four indicators that examine whether the legislature can question executive branch officials in practice; whether the legislature and other bodies (comptroller general, general prosecutor or ombudsman) are able to investigate the executive in practice; and, finally, whether legislature opposition parties are able to exercise oversight over the governing party ${ }^{3}$.

We also include the widely used composite democracy index provided by Polity IV (Marshall 2013) as an alternative measure, which is aggregated by weighted addition of five subcomponents: competitiveness and openness of executive recruitment, competitiveness and regulation of political participation, and constraints on the chief executive (a bigger weigh is assigned to this sub-component). The resulting polity scale ranges from +10 (strongly democratic) to -10 (strongly autocratic) and the data is available from 1946 to $2012^{4}$.

Quality of government is a rather broad term, which can be both conceptualized and measured in various ways. Previous research has used measures including corruption, government effectiveness and rule of law. This paper relies on a more specific definition of QoG as "the impartiality of institutions that exercise government authority", provided by Rothstein and Teorell (2008:165) and is measured by combining into an index five V-Dem indicators that focus on corruption in state institutions. Throughout this paper we refer to this index as the nocorruption index. The exact language of the corruption indicators that constitute this measure can be found in the Appendix in Table A.1. The literature has pointed out that corruption is an important indication of bad governance, and may lead to the distorted distribution of public resources (Diamond 2007, Rothstein 2011).

As McMann et al (2015) have argued there are three main advantages of the no-corruption index based on the V-Dem data than other widely used measures of corruption: content validity, coverage and sources used to collect the data:

First, the V-Dem corruption indictors resonate with the accepted academic usage of the term corruption as the use of public office for private gain (Gerring, 2001:117-119, McMann et al 2015). The five indicators that constitute the index look at levels of corruption within the main public officeholders: the executive, members of the legislature, members of the judiciary, and public sector employees. It is consistent with our inquiry of exploring the effects of the general quality of government, the corruption in the state institutions and public officials as an indication, on health outcome. In addition, the wording of the indicators captures different corruption forms, including bribes, undocumented extra payments, kickbacks, theft, embezzlement and misappropriation. Surveys of firms or the general public, on the other hand, provide narrower

\footnotetext{
${ }^{3}$ For the exact question formulation of the indicators going into the index, see the Appendix, Table A.1 and A.2.

${ }^{4}$ The electoral accountability index is correlated to the polity score at 0.87 , while the legislative constraint index is correlated to it at 0.85 .
} 
perspectives on the use of public office for private gain than judgments of specialists in the politics of the country (McMann et al 2015).

Secondly, as stressed in the previous section, one unique feature of the V-Dem data is that it allows over-time and cross-country comparisons of democracies going all the way back to 1900. This advantage allows an important contribution to the study of democracy and quality of government as existing measures are not designed for panel analysis. With a sensitive topic such as corruption, potential biases introduced by limited coverage of the dataset over time and across countries could be particularly influential. Missing data could possibly be not missing at random but selection bias could be introduced in the process of deciding which cases to include or exclude (McMann et al 2015, Treisman 2007). Thus, big variation of levels and types of corruption could be lost as a result of limited coverage of data. Table 1 compares the nocorruption index and three other commonly used measures (TI Corruption Perceptions Index, and two World Bank Worldwide Governance Indicators (Rule of Law and Government Effectiveness) (Transparency International 2013, Kaufmann et al 2010). The table shows that the time range covered by the three measures reaches 14 years for maximum 158 countries, compared to the 172 countries for 114 years of the V-Dem data. The correlation coefficients of the index used in this paper with the alternative measures are between .85 and .88. That is, country-years rated as more corrupt by extant measures of corruption also tend to be rated as more corrupt by the V-Dem index, and the other way around ${ }^{5}$. The pattern is also evident in Figure 1, in which the standardized average scores across countries on these indices are shown. We also include these alternative measures in the analyses to verify the findings.

Table 1. The Comparison of Governance Indices

\begin{tabular}{|c|c|c|}
\hline & $\begin{array}{c}\text { Correlation coefficients with V- } \\
\text { Dem no-corruption index }\end{array}$ & Coverage \\
\hline $\begin{array}{c}\text { TI Corruption } \\
\text { Perceptions Index }\end{array}$ & 0.8878 & $1995-2013$ \\
\hline WB Rule of Law & 0.8710 & N: $185 \mathrm{n}: 2429 \bar{N}: 128 \bar{T}: 13$ \\
& & N: $195 \mathrm{n}: 2686 \bar{N}: 158 \bar{T}: 14$ \\
WB Government \\
Effectiveness
\end{tabular}

${ }^{5}$ For a more detailed discussion of the systematic differences between the V-Dem corruption measures and some other existing indices see McMann et al. (2015). 
Figure 1. Country Average Scores on Different Governance Indices

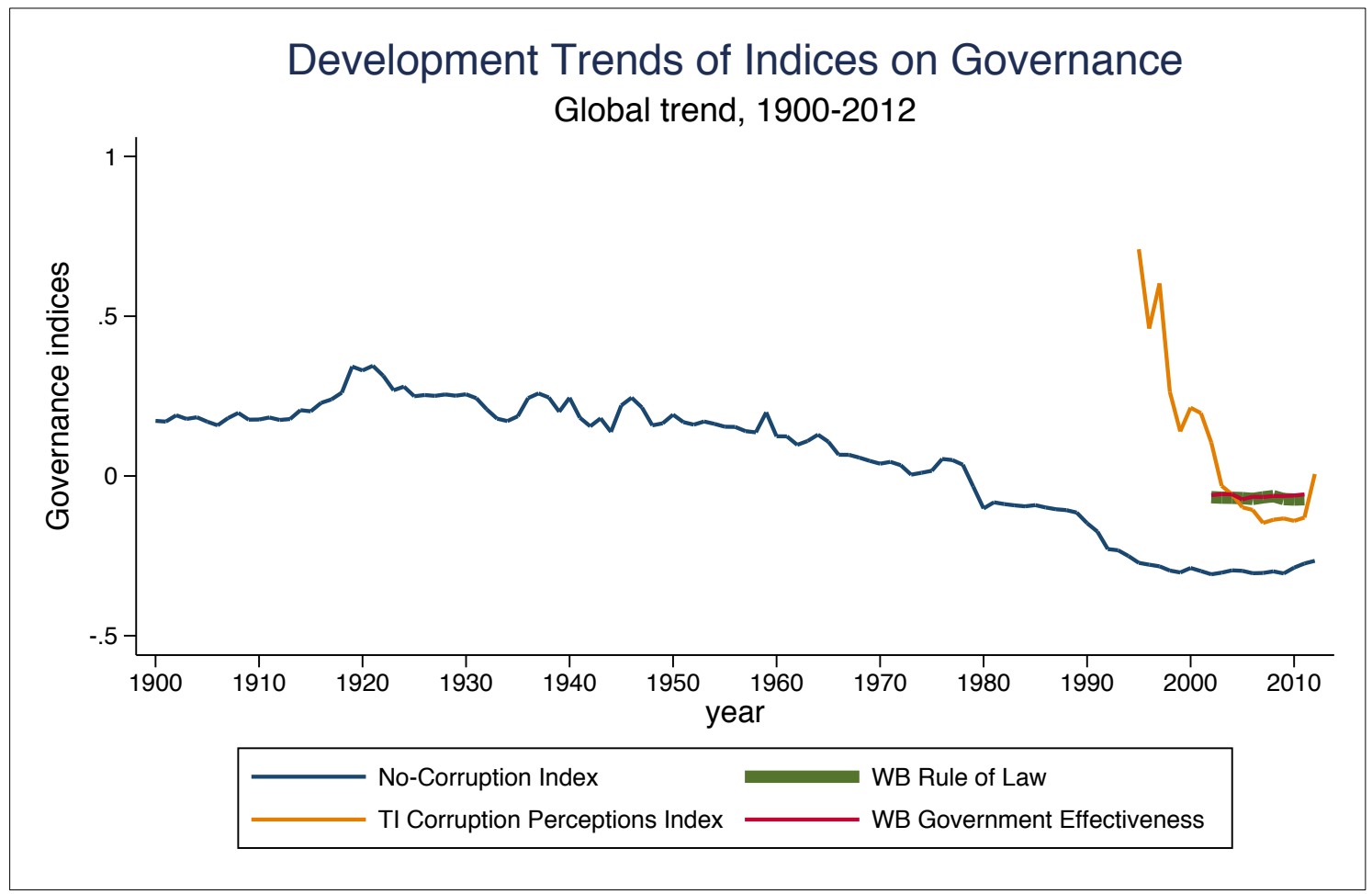

Finally, the variables used in the no-corruption index follow the same data collection method for all countries to facilitate cross-national analysis. In comparison, datasets that rely on different sources across countries are not ideal for this purpose (McMann et al 2015). Thus, the V-Dem no-corruption index also demonstrates consistency across time and countries. In addition, the inclusion of numerous possible forms of corruption makes our indicators more broadly applicable and less restrictive across contexts (Gerring, 2001:121-124), since the index takes into account the fact that some forms of corruption are more widespread in some place and time than in others.

\subsection{Dependent Variable}

Consistent with existing research on the effects of democracy and governance on health outcomes (Shandra et al. 2004, Ross 2006, Rothstein \& Holmberg 2010, Norris 2012, Gerring et al. 2012), we utilize the data on infant and child mortality rate as an indication of population health. The main dependent variable we use is infant mortality rate calculated as the number of deaths prior to age 1 per 1000 live births in a year. The base variable is drawn from Gapminder ${ }^{6}$,

\footnotetext{
${ }^{6}$ Gapminder. Accessed May 15, 2014. http://www.gapminder.org/data/
} 
with additional data imputed from Clio-Infra ${ }^{7}$. The resulting measure covers all countries in the V-Dem dataset from 1900 to 2012 although the coverage is limited for certain countries in the beginning of the century ${ }^{8}$.

The measures on infant and child mortality rate are transformed by the natural logarithm in all following models (except for the poisson model included in the Appendix Table A.4), consistent with previous research done on the topic as the distribution of this variable is right-skewed reflecting the general downward trend in mortality in many developed countries in recent decades. In addition, the theoretical argument behind the logged transformation is that mortality rate is more resilient at higher rates as improvements in number of mortality are easier to achieve when the rate is higher.

We also use a measure for mortality rate under 5 as an alternative dependent variable. The data is provided by the Inter-agency Group for Child Mortality Estimation (IGME, 2004) that measures the probability per 1,000 that a newborn baby will die before reaching age five, if subject to current age-specific mortality rates. This time-series, however, covers only the period from 1960 to 2010.

\subsection{Controls}

We include several likely confounders as control variables in our models. In order to take into account the general level of development of a country, we include a measure for GDP per capita, transformed by the natural logarithm ${ }^{9}$ and an additional indicator for urbanization rate, measured as ratio of urban population to total population ${ }^{10}$. We also include a V-Dem measure for "stateness" - domestic autonomy that gives information whether the state is autonomous from the control of other states with respect to the conduct of domestic policy, where high values indicate full autonomy and low values refer to an authority exercised by external power (see the Appendix Table A.1). Since the infant mortality rate rises significantly when a country is under conflict, we also include two dummy variables that identify whether the country participated in an international armed conflict or whether it experienced an internal armed conflict ${ }^{11}$ in the year. To measure the overall regime performance, we include an indicator for GDP growth rate ${ }^{12}$. Finally, to control for oil rents, we use a variable that captures the real value of petroleum produced per

\footnotetext{
${ }^{7}$ Clio-Infra. Accessed May 27, 2014. http://www.clio-infra.eu/. Missing data within a time-series is interpolated for each variable, increasing the number of observations as follows: (a): from 11592 to 12185; (b): from 567 to 5369. Missing data for (a) is imputed with (b), and increasing the number of observations from 12185 to 13566.

${ }^{8}$ See the Appendix Table A.5 for a list of country-years included in the analyses.

${ }^{9}$ Source: The Maddison-Project (2013).

${ }^{10}$ Sources: Clio Infra (clio-infra.eu).

${ }^{11}$ Both variables are extracted from Clio Infra, drawing on Brecke (2001).

${ }^{12}$ Source: The Maddison-Project (2013)
} 
capita. ${ }^{13}$ The descriptive statistics of variables included in the analyses can be found in the Appendix in Table A.3.

\section{Results}

\subsection{Democracy or Quality of Government?}

To test our hypothesis on the effects of democracy and governance on health outcomes, we estimate time-series cross-sectional models with fixed effects. To begin with, as explanatory variables we use indicators that have been previously used in similar studies to replicate the findings. The results are included in Table 2.

Table 2. Regression estimates of the effect of democracy and governance on infant mortality

\begin{tabular}{|c|c|c|c|c|c|c|c|}
\hline & \multirow{2}{*}{\multicolumn{7}{|c|}{$\begin{array}{c}(3) \\
\text { Infant mortality rate, logged }\end{array}$}} \\
\hline & & & & & & & \\
\hline Polity & $\begin{array}{l}-0.00326 \\
{[0.00173]}\end{array}$ & $\begin{array}{l}-0.000377 \\
{[0.000598]}\end{array}$ & $\begin{array}{c}-0.00105 \\
{[0.000750]}\end{array}$ & $\begin{array}{l}-0.000532 \\
{[0.000590]}\end{array}$ & & & \\
\hline Electoral Principle & & & & & $\begin{array}{c}-0.00636 \\
{[0.0180]}\end{array}$ & $\begin{array}{c}-0.092 * * * \\
{[0.0221]}\end{array}$ & $\begin{array}{l}-0.0129 \\
{[0.0178]}\end{array}$ \\
\hline WB Rule of Law & $\begin{array}{l}-0.0426^{*} \\
{[0.0190]}\end{array}$ & $\begin{array}{l}-0.0149 * \\
{[0.00653]}\end{array}$ & & & $\begin{array}{l}-0.0188^{* *} \\
{[0.00655]}\end{array}$ & & \\
\hline $\begin{array}{l}\text { TI Corruption } \\
\text { Perceptions Index }\end{array}$ & & & $\begin{array}{l}-0.00533 \\
{[0.00281]}\end{array}$ & & & $\begin{array}{l}-0.00468 \\
{[0.00284]}\end{array}$ & \\
\hline $\begin{array}{l}\text { WB Government } \\
\text { Effectiveness }\end{array}$ & & & & $\begin{array}{l}-0.0134 * \\
{[0.00643]}\end{array}$ & & & $\begin{array}{l}-0.00971 \\
{[0.00643]}\end{array}$ \\
\hline GDP per capita, logged & $\begin{array}{c}-0.590^{* * *} \\
{[0.0204]}\end{array}$ & $\begin{array}{c}-0.0323 * * * \\
{[0.00905]}\end{array}$ & $\begin{array}{c}-0.0683 * * * \\
{[0.0131]}\end{array}$ & $\begin{array}{c}-0.0318^{* * *} \\
{[0.00912]}\end{array}$ & $\begin{array}{l}-0.0322^{* *} \\
{[0.00979]}\end{array}$ & $\begin{array}{c}-0.069 * * * \\
{[0.0130]}\end{array}$ & $\begin{array}{l}-0.0327 * * \\
{[0.00999]}\end{array}$ \\
\hline Urbanization rate & $\begin{array}{c}-3.649 * * * \\
{[0.192]}\end{array}$ & $\begin{array}{c}-0.120 \\
{[0.0841]}\end{array}$ & $\begin{array}{l}-0.181 \\
{[0.103]}\end{array}$ & $\begin{array}{c}-0.132 \\
{[0.0846]}\end{array}$ & $\begin{array}{l}-0.0169 \\
{[0.0842]}\end{array}$ & $\begin{array}{l}-0.110 \\
{[0.103]}\end{array}$ & $\begin{array}{l}-0.0246 \\
{[0.0848]}\end{array}$ \\
\hline Lagged DV & & $\begin{array}{l}0.955^{* * *} \\
{[0.0130]}\end{array}$ & $\begin{array}{l}0.930 * * * \\
{[0.0160]}\end{array}$ & $\begin{array}{l}0.953^{* * *} \\
{[0.0131]}\end{array}$ & $\begin{array}{l}0.956 * * * \\
{[0.0131]}\end{array}$ & $\begin{array}{l}0.934 * * * \\
{[0.0160]}\end{array}$ & $\begin{array}{l}0.957 * * * \\
{[0.0132]}\end{array}$ \\
\hline _cons & $\begin{array}{c}9.999 * * * \\
{[0.156]}\end{array}$ & $\begin{array}{c}0.418^{* * *} \\
{[0.105]}\end{array}$ & $\begin{array}{c}0.845^{* * *} \\
{[0.145]}\end{array}$ & $\begin{array}{c}0.427 * * * \\
{[0.105]}\end{array}$ & $\begin{array}{c}0.361 * * \\
{[0.111]}\end{array}$ & $\begin{array}{c}0.846 * * * \\
{[0.145]}\end{array}$ & $\begin{array}{c}0.371 * * * \\
{[0.111]}\end{array}$ \\
\hline Country FE & $\mathrm{V}$ & $\mathrm{v}$ & $\mathrm{v}$ & $\mathrm{v}$ & $\mathrm{v}$ & $\mathrm{v}$ & $\mathrm{v}$ \\
\hline Year FE & & $\mathrm{v}$ & $\mathrm{v}$ & $\mathrm{v}$ & $\mathrm{v}$ & $\mathrm{v}$ & $\mathrm{v}$ \\
\hline Lagged DV & & $\mathrm{v}$ & $\mathrm{v}$ & $\mathrm{v}$ & $\mathrm{v}$ & $\mathrm{v}$ & $\mathrm{v}$ \\
\hline Countries & 148 & 148 & 146 & 148 & 144 & 143 & 144 \\
\hline $\mathrm{N}$ & 1678 & 1678 & 1605 & 1677 & 1646 & 1571 & 1645 \\
\hline $\begin{array}{l}\text { Log likelihood } \\
\text { adj. R-sq (within) }\end{array}$ & $\begin{array}{c}1223.6 \\
0.550\end{array}$ & $\begin{array}{c}3035.8 \\
0.948\end{array}$ & $\begin{array}{c}2779.2 \\
0.934\end{array}$ & $\begin{array}{c}3033.3 \\
0.947\end{array}$ & $\begin{array}{c}2984.8 \\
0.949\end{array}$ & $\begin{array}{c}2726.0 \\
0.935\end{array}$ & $\begin{array}{c}2979.4 \\
0.948\end{array}$ \\
\hline
\end{tabular}

All independent variables are lagged for one year. Coefficients of yearly dummies are not reported. Standard error in brackets $*$ $\mathrm{p}<0.05^{* *} \mathrm{p}<0.01 * * * \mathrm{p}<0.001$.

Across all models the independent variables are lagged by one year. In model 1, only country fixed-effects are included, while in all other models we add yearly dummies and lagged dependent variable. Yearly dummies are included to control for the general global health trends and other contemporaneous factors. One-year lagged dependent variable is added to the models

\footnotetext{
${ }^{13}$ Sources: Haber and Menaldo (2011)
} 
to test whether the change of infant mortality rate from one year to another is influenced by democracy and quality of government. A lagged dependent variable also serves as a proxy for omitted variables and controls for the possibility of temporal correlation.

Overall the results presented in Table 2 replicate the finding that there is a positive effect of good governance on health outcomes. The polity scores, used as a measure for level of democracy, do not come out as a statistically significant predictor of infant mortality in any of the models, while the indicators on rule of law and government effectiveness (WB) are estimated to reduce the rate of infant mortality (Models 1, 2 and 4). Although the TI measure on corruption does not cross the significance threshold (Model 3), we find that the other two proxies for governance are significant predictors of mortality, especially when adequate controls are included. In Models 5, 6 and 7 we include the V-Dem electoral principle of democracy index as one of the main explanatory variables. Across models the electoral democracy index shows statistically significant effect only in one of the specifications, while the WB rule of law indicator retains its statistical significance.

As the previous section has pointed out, the commonly used indicators of governance included in Table 2 are measured for the recent two decades, thus the total number of observations in the regression analysis above is around 1600. To test whether the omitted countries and years in the first set of models are introducing bias, we include the no-corruption index as a proxy for governance in the models presented in Table 3. Table A.5 in the Appendix compares countries and years covered in the first model of Table 2 and 3.

The most important findings from this round of analysis are that the electoral component index and the legislative control index have consistent positive effects on health outcomes, even when the lagged dependent variable and other relevant controls are included in the model (GDP growth, oil rents, domestic autonomy and occurrence of conflicts). The effects of democracy, either measured as the quality of competitive elections or the capacity of legislative constraints, are largely reduced but still significant if the lagged dependent variable is controlled. Table A.4 in the Appendix shows the results of additional robustness checks, including those based on imputed data, and the same patterns prevail.

Based on model 2 and 5, a one standard deviation increase on the electoral principle or the legislative constraint index is associated with a decrease in infant mortality rate of more than 1 per 1000. However, the effects of the no-corruption index are less clear as the indicator does not show statistically significant results in the presence of other important factors to health. In one of the alternative specifications where mortality rate under 5 years is used as the dependent variable 
(sample covers 1960-2012), the indicator even has a positive effect on mortality rates, opposite to the negative relationship as we expected. 
Table 3. Regression estimates of the effect of democracy and governance on health, 1900-2012

\begin{tabular}{|c|c|c|c|c|c|c|c|c|}
\hline & $(1)$ & $(2)$ & (3) & $(4)$ & (5) & $(6)$ & $(7)$ & $(8)$ \\
\hline & \multicolumn{6}{|c|}{ Infant Mortality Rate, logged } & \multicolumn{2}{|c|}{$\begin{array}{c}\text { Mortality Rate Under 5, } \\
\text { logged }\end{array}$} \\
\hline Electoral Principle & $\begin{array}{l}-0.485^{* * *} \\
{[0.0285]}\end{array}$ & $\begin{array}{l}-0.0393 * * * \\
{[0.00736]}\end{array}$ & $\begin{array}{l}-0.0520^{* * *} \\
{[0.00853]}\end{array}$ & & & & $\begin{array}{l}-0.0308^{* * *} \\
{[0.00515]}\end{array}$ & \\
\hline Legislative Constraints & & & & $\begin{array}{l}-0.259 * * * \\
{[0.0217]}\end{array}$ & $\begin{array}{l}-0.0208 * * * \\
{[0.00555]}\end{array}$ & $\begin{array}{l}-0.0238^{* * *} \\
{[0.00632]}\end{array}$ & & $\begin{array}{l}-0.0378^{* * *} \\
{[0.00351]}\end{array}$ \\
\hline No-Corruption & $\begin{array}{l}-0.0283 \\
{[0.0326]}\end{array}$ & $\begin{array}{l}-0.0292 * * * \\
{[0.00838]}\end{array}$ & $\begin{array}{l}-0.00768 \\
{[0.0102]}\end{array}$ & $\begin{array}{l}-0.0427 \\
{[0.0323]}\end{array}$ & $\begin{array}{l}-0.0321 * * * \\
{[0.00821]}\end{array}$ & $\begin{array}{l}-0.0180 \\
{[0.00988]}\end{array}$ & $\begin{array}{l}0.0565^{* * *} \\
{[0.00586]}\end{array}$ & $\begin{array}{l}0.0627 * * * \\
{[0.00566]}\end{array}$ \\
\hline Urbanization Rate & $\begin{array}{l}-2.406 * * * \\
{[0.0546]}\end{array}$ & $\begin{array}{l}0.00696 \\
{[0.0175]}\end{array}$ & $\begin{array}{l}-0.00650 \\
{[0.0193]}\end{array}$ & $\begin{array}{l}-2.605 * * * \\
{[0.0520]}\end{array}$ & $\begin{array}{l}0.00292 \\
{[0.0173]}\end{array}$ & $\begin{array}{l}-0.0108 \\
{[0.0191]}\end{array}$ & $\begin{array}{l}0.0142 \\
{[0.0133]}\end{array}$ & $\begin{array}{l}0.0136 \\
{[0.0130]}\end{array}$ \\
\hline Lagged DV & & $\begin{array}{l}0.943 * * * \\
{[0.00340]}\end{array}$ & $\begin{array}{l}0.936^{* * *} \\
{[0.00397]}\end{array}$ & & $\begin{array}{l}0.944^{* * *} \\
{[0.00333]}\end{array}$ & $\begin{array}{l}0.938^{* * * *} \\
{[0.00390]}\end{array}$ & $\begin{array}{l}0.986^{* * *} \\
{[0.00276]}\end{array}$ & $\begin{array}{l}0.987 * * * \\
{[0.00270]}\end{array}$ \\
\hline GDP Growth Rate & & & $\begin{array}{l}-0.0009 * * * \\
{[0.00018]}\end{array}$ & & & $\begin{array}{l}-0.0009 * * * \\
{[0.00018]}\end{array}$ & & \\
\hline $\begin{array}{l}\text { Armed Conflict, } \\
\text { International } \\
\text { Armed Conflict, } \\
\text { Internal }\end{array}$ & & & $\begin{array}{l}0.00556 \\
{[0.00410]} \\
-0.00522 \\
{[0.00362]}\end{array}$ & & & $\begin{array}{l}0.00734 \\
{[0.00402]} \\
-0.00488 \\
{[0.00357]}\end{array}$ & & \\
\hline _cons & $\begin{array}{l}11.47 * * * \\
{[0.0761]}\end{array}$ & $\begin{array}{l}0.360 * * * \\
{[0.0463]}\end{array}$ & $\begin{array}{l}0.409 * * * \\
{[0.0530]}\end{array}$ & $\begin{array}{l}11.74 * * * \\
{[0.0752]}\end{array}$ & $\begin{array}{l}0.373 * * * \\
{[0.0436]}\end{array}$ & $\begin{array}{l}0.409 * * * \\
{[0.0510]}\end{array}$ & $\begin{array}{l}-0.0652 * \\
{[0.0274]}\end{array}$ & $\begin{array}{l}-0.0600 * \\
{[0.0269]}\end{array}$ \\
\hline Country FE & $\mathrm{v}$ & $\mathrm{v}$ & $\mathrm{v}$ & $\mathrm{v}$ & $\mathrm{v}$ & $\mathrm{v}$ & $\mathrm{v}$ & $\mathrm{v}$ \\
\hline Year FE & & $\mathrm{v}$ & $\mathrm{v}$ & $\mathrm{v}$ & & $\mathrm{v}$ & $\mathrm{v}$ & $\mathrm{v}$ \\
\hline Lagged DV & & $\mathrm{v}$ & $\mathrm{v}$ & $\mathrm{v}$ & & $\mathrm{v}$ & $\mathrm{v}$ & $\mathrm{v}$ \\
\hline Countries & 146 & 146 & 106 & 146 & 146 & 106 & 145 & 145 \\
\hline $\mathrm{N}$ & 8055 & 7942 & 5739 & 8217 & 8088 & 5851 & 5222 & 5281 \\
\hline Log likelihood & -2642.8 & 9027.0 & 7044.5 & -2797.4 & 9220.4 & 7184.7 & 9955.2 & 10130.3 \\
\hline
\end{tabular}




\subsection{The Incomplete Sample}

To explore why the results from the two tables presented above differ so extensively we first analyze the difference in the samples. The number of cases in Table 3 compared to Table 2 increases approximately 3.5 times in the models when all control variables are included and 5 times in the baseline models. The list of the countries and the year-range included in the regression analysis, documented in Table A.5 in the Appendix, reveals that the difference in the number of observations comes from the much richer data of country-years prior to 1996.

To examine how the difference in data coverage affects the variations of the main explanatory variables, we first depict the relationship between the levels of democracy measured as the quality of elections and the no-corruption index of all observations (country-years) from 1900 to 2012. Figure 2 shows the scatterplot. The figure suggests that across the entire time period, we can observe all different kinds of combinations between these two indicators. In addition to data points in the first and the third quadrants, there are some country-years rated high on the nocorruption but low on the electoral index, while others have free and fair elections but lag behind in terms of the quality of government.

Figure 2: The relationship between electoral principle and no-corruption indices (19002012)

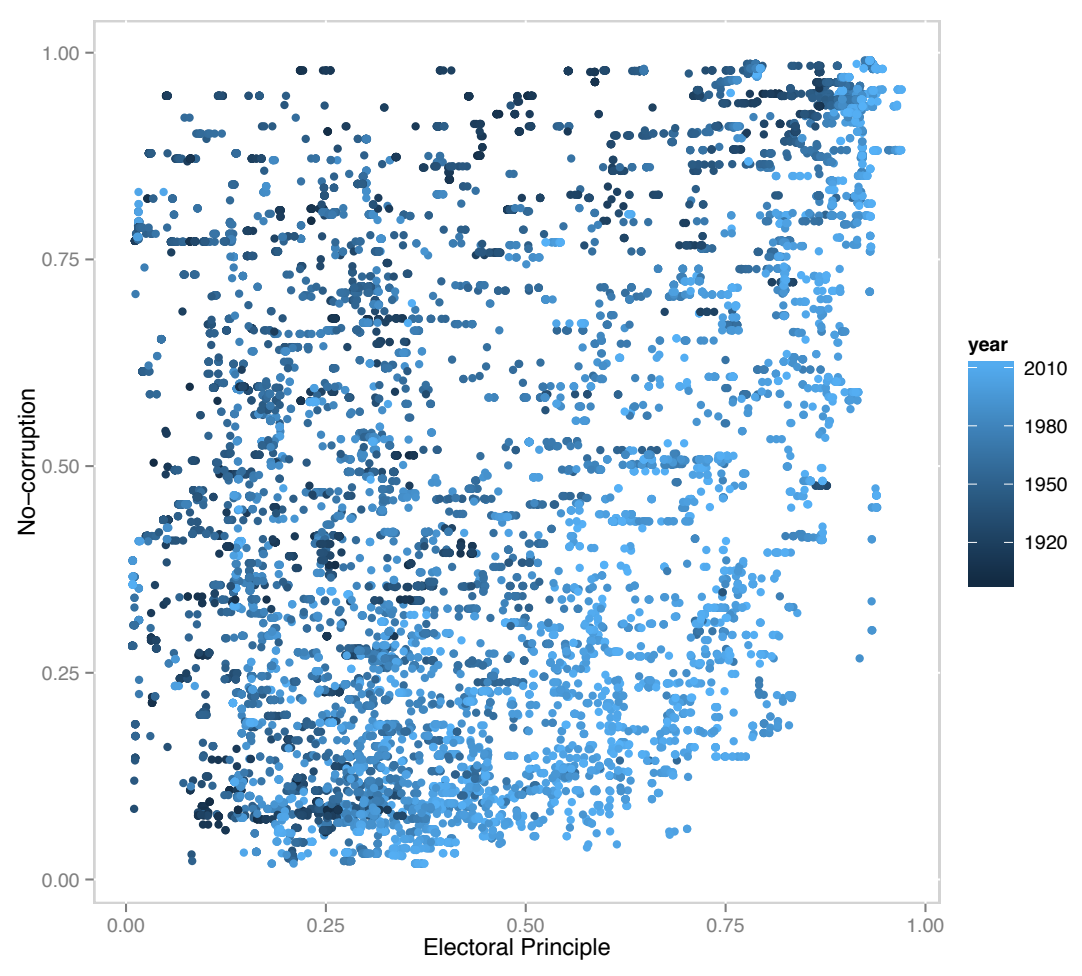


In the figure, colors represent different years, and suggest that the observed combinations of the values of electoral and no-corruption indices seem to vary over time. Back in time, there were more countries that had a high quality of government but did not hold competitive elections; while recently, the combination of low values on the no-corruption index and high-values on the electoral index is more common.

To further verify this pattern, Figure 3 shows the scatterplot between the no-corruption and the electoral indices but only for observations after 1996 when the WB and TI governance indicators start to be measured. The figure shows that there is a roughly positive relationship between the two indicators. In addition, there are many countries that hold competitive elections but have corrupt governments. Contrary to the previous figure that covers the entire period between 1900 and 2012, it is rare to observe the combination of low values on the electoral index but high values on the governance index. The same pattern prevails in Figure 4 and 5, when the polity scores are used as the measure of regime types and TI corruption perception index as the measure of governance.

Figure 3: The relationship between electoral principle and no-corruption indices (19962012)

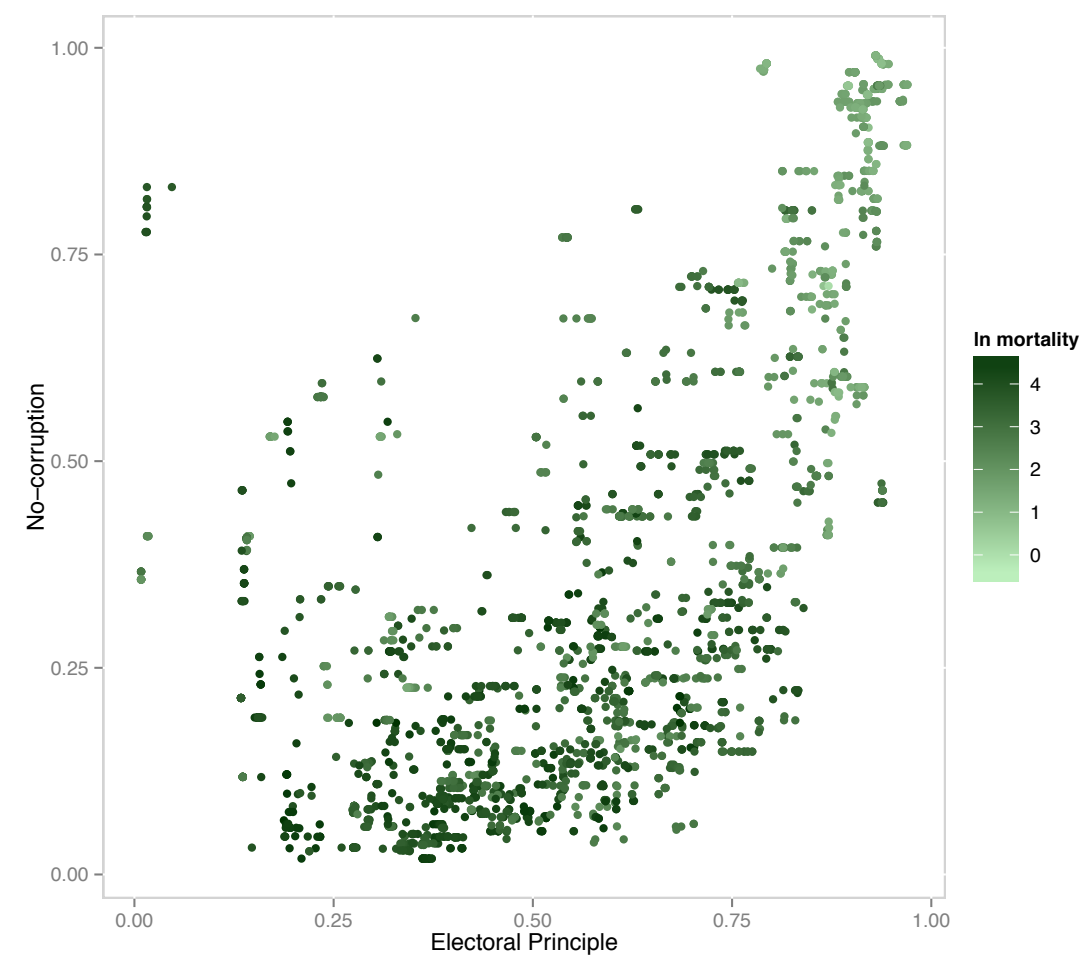

These plots show that a sample after 1996 does not reflect all possible variations of combinations between the two main explanatory variables. However, the existing governance 
indicators used in previous research are only measured for the most recent two decades. To verify whether it is the limited coverage that results in the conflicting results shown in Table 2 and 3, we estimate the same models as those in Table 3 but limit the analysis only to observations after 1996. The results are presented in models 1 to 6 in Table 4.

The model coefficients are consistent with some previous studies, and show that for this time period, the no-corruption index has more consistent and significant positive effects on health than regime types, either measured as competitive elections, legislative constraints, or the polity scores.

Figure 4: The relationship between polity and no-corruption indices (1996-2012)

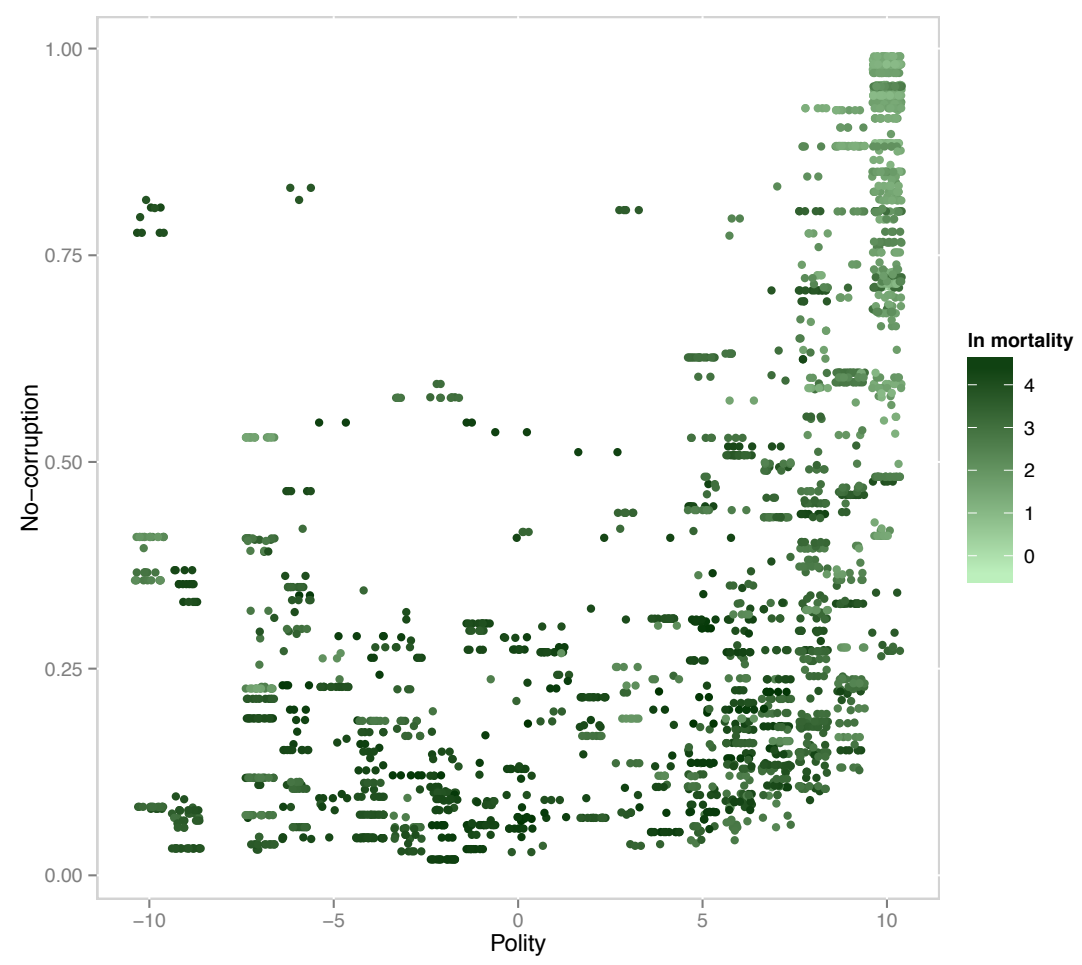


Figure 5: The relationship between electoral principle and TI corruption perception indices (1996-2012)

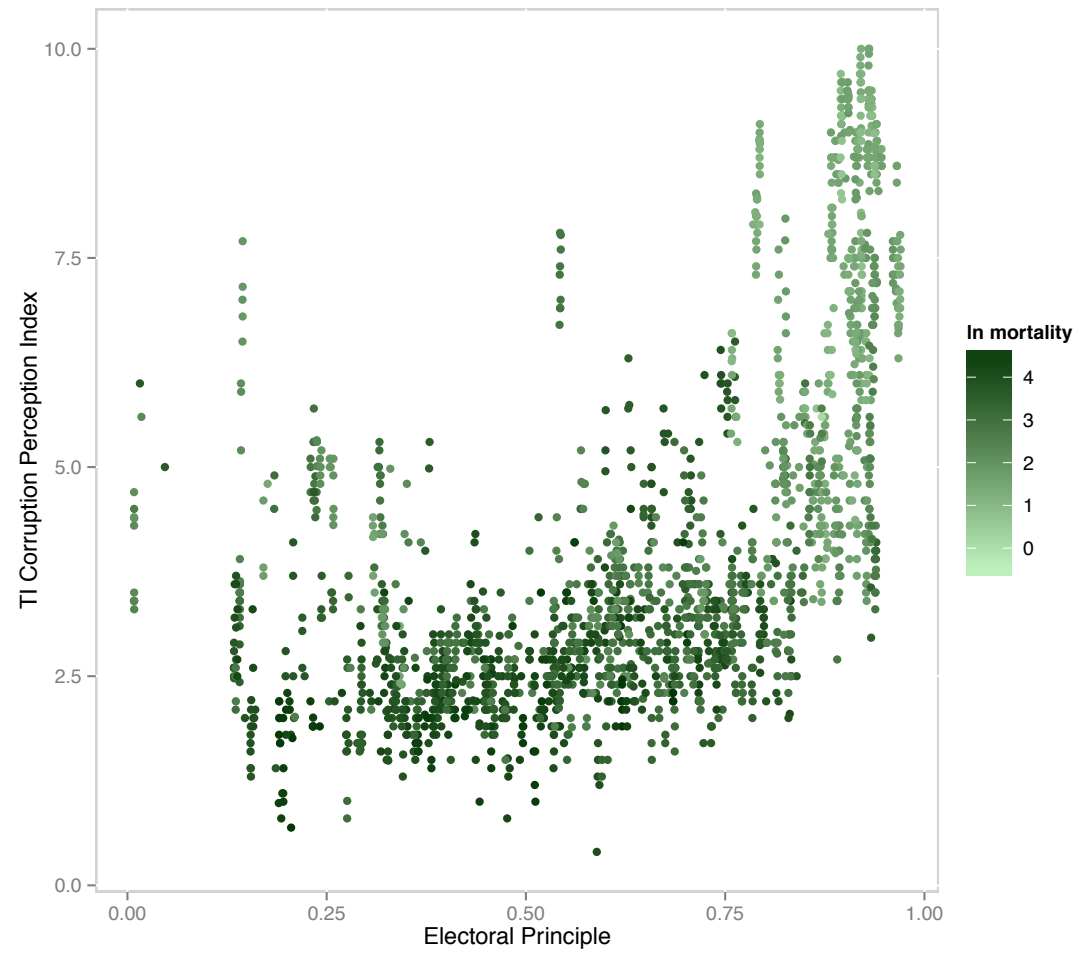

Table 4. Regression estimates of the effect of democracy and governance on health

\begin{tabular}{|c|c|c|c|c|c|c|c|}
\hline & $\begin{array}{l}(1) \\
1996-\end{array}$ & $\begin{array}{l}(2) \\
1996-\end{array}$ & $\begin{array}{l}\text { (3) } \\
\text { 1996- } \\
\text { Infant }\end{array}$ & $\begin{array}{l}\text { (4) } \\
\text { 1996- } \\
\text { Mortality Rat }\end{array}$ & $\begin{array}{l}\text { (5) } \\
1996- \\
\text {, logged }\end{array}$ & $\begin{array}{l}(6) \\
1996-\end{array}$ & $\begin{array}{l}(7) \\
1946-\end{array}$ \\
\hline Electoral Principle & $\begin{array}{c}-0.00288 \\
{[0.0504]}\end{array}$ & $\begin{array}{c}0.0661 \\
{[0.0339]}\end{array}$ & & & & & \\
\hline Legislative Constraints & & & $\begin{array}{c}-0.106^{* *} \\
{[0.0404]}\end{array}$ & $\begin{array}{l}0.0545^{*} \\
{[0.0272]}\end{array}$ & & & \\
\hline Polity & & & & & $\begin{array}{c}-0.0052 * * * \\
{[0.00156]}\end{array}$ & $\begin{array}{l}-0.00043 \\
{[0.00105]}\end{array}$ & $\begin{array}{c}-.00018^{* * *} \\
{[0.00238]}\end{array}$ \\
\hline No-Corruption Index & $\begin{array}{l}-0.132^{*} \\
{[0.0610]}\end{array}$ & $\begin{array}{c}-0.106^{* *} \\
{[0.0409]}\end{array}$ & $\begin{array}{l}-0.0703 \\
{[0.0630]}\end{array}$ & $\begin{array}{c}-0.114 * * \\
{[0.0421]}\end{array}$ & $\begin{array}{c}-0.116 \\
{[0.0602]}\end{array}$ & $\begin{array}{c}-0.114 * * \\
{[0.0402]}\end{array}$ & $\begin{array}{l}-0.0105 \\
{[0.0087]}\end{array}$ \\
\hline GDP per capita,logged & $\begin{array}{c}-0.689 * * * \\
{[0.0187]}\end{array}$ & $\begin{array}{c}-0.184 * * * \\
{[0.0166]}\end{array}$ & $\begin{array}{c}-0.687 * * * \\
{[0.0187]}\end{array}$ & $\begin{array}{c}-0.183^{* * *} \\
{[0.0165]}\end{array}$ & $\begin{array}{c}-0.685^{* * *} \\
{[0.0189]}\end{array}$ & $\begin{array}{c}-0.184 * * * \\
{[0.0167]}\end{array}$ & $\begin{array}{c}-.00125^{* * *} \\
{[0.0037]}\end{array}$ \\
\hline Urbanization Rate & $\begin{array}{c}-3.481 * * * \\
{[0.163]}\end{array}$ & $\begin{array}{l}0.0769 \\
{[0.142]}\end{array}$ & $\begin{array}{c}-3.485^{* * *} \\
{[0.161]}\end{array}$ & $\begin{array}{l}0.0932 \\
{[0.141]}\end{array}$ & $\begin{array}{c}-3.499 * * * \\
{[0.166]}\end{array}$ & $\begin{array}{l}0.0617 \\
{[0.144]}\end{array}$ & $\begin{array}{c}0.0366^{*} \\
{[0.018]}\end{array}$ \\
\hline Lagged DV & & $\begin{array}{c}0.421 * * * \\
{[0.0201]}\end{array}$ & & $\begin{array}{c}0.424 * * * \\
{[0.0199]}\end{array}$ & & $\begin{array}{c}0.418^{* * *} \\
{[0.0202]}\end{array}$ & $\begin{array}{c}0.935^{* * *} \\
{[0.0038]}\end{array}$ \\
\hline _cons & $\begin{array}{c}10.75^{* * *} \\
{[0.141]}\end{array}$ & $\begin{array}{c}3.319 * * * \\
{[0.182]}\end{array}$ & $\begin{array}{c}10.78^{* * *} \\
{[0.139]}\end{array}$ & $\begin{array}{c}3.298^{* * *} \\
{[0.181]}\end{array}$ & $\begin{array}{c}10.75^{* * *} \\
{[0.142]}\end{array}$ & $\begin{array}{c}3.387 * * * \\
{[0.182]}\end{array}$ & $\begin{array}{c}0.269^{* * *} \\
{[0.0414]}\end{array}$ \\
\hline Country FE & $\mathrm{V}$ & $\mathrm{V}$ & $\mathrm{V}$ & $\mathrm{V}$ & $\mathrm{V}$ & $\mathrm{V}$ & $\mathrm{V}$ \\
\hline Year FE & & $\mathrm{v}$ & & $\mathrm{v}$ & & $\mathrm{v}$ & $\mathrm{v}$ \\
\hline Lagged DV & & $\mathrm{v}$ & & $\mathrm{v}$ & & $\mathrm{v}$ & $\mathrm{v}$ \\
\hline $\mathrm{N}$ & 2012 & 2012 & 2030 & 2030 & 1971 & 1971 & 6327 \\
\hline Countries & 143 & 143 & 144 & 144 & 140 & 140 & 143 \\
\hline Log likelihood & 1504.3 & 2328.6 & 1521.6 & 2358.0 & 1473.4 & 2289.5 & 8084.4 \\
\hline adj. R-sq & 0.602 & 0.823 & 0.603 & 0.824 & 0.606 & 0.826 & 0.987 \\
\hline
\end{tabular}

All independent variables are lagged for one year. Coefficients of yearly dummies are not reported. Standard error in brackets * $\mathrm{p}<0.05^{* *} \mathrm{p}<0.01 * * * \mathrm{p}<0.001$. 
In model 7 , we conduct the same analysis with polity scores as the measure of regime type and for the entire time period since the polity data is available (1946). Similar with results shown in Table 3, democracy significantly reduces infant mortality rates, while the effects of corrupt governance are less clear. These analyses suggest that the conflicting results identified in the literature and also in the previous section are to a larger extent due to the limited coverage of samples than different measures of democracy. The result that quality of government rather than democracy is the crucial determinant of health holds only for a sample of most recent decades, which does not reflect the entire range of variations.

We also estimate the model for samples of other time periods. For example, the indicator of mortality rates under 5, provided by the United Nations IGME, is measured for years after 1960. As model 7 and 8 in Table 3 and Table A.6 in the Appendix show, for a subsample of years after 1960, both infant and child mortality rates increase with higher levels of quality of government and decrease with higher levels of democracy. Table A.6 in the Appendix also includes the analyses for other time periods, and the results suggest that the effects of the no-corruption index vary substantially across subsamples of different time periods. Democracy more consistently leads to the improvement of health, except for the subsample of the most recent two decades when the variations in levels of corruption across non-democratic countries are largely reduced. Further research is required to examine whether the different effects of corruption across subsamples are due to that the impacts of governance are contingent on other factors or simply the results of biased slices of countries.

\subsection{Vertical and Horizontal Accountability}

To test the hypothesis that the combination of both vertical and horizontal accountability mechanisms especially urges politicians to provide public goods (hypothesis 2), we include the interaction term between the electoral principle and legislative constraint indices in the analyses. The results are shown in Table 5. 
Table 5. Regression estimates of the joint effect of vertical and horizontal accountability mechanisms

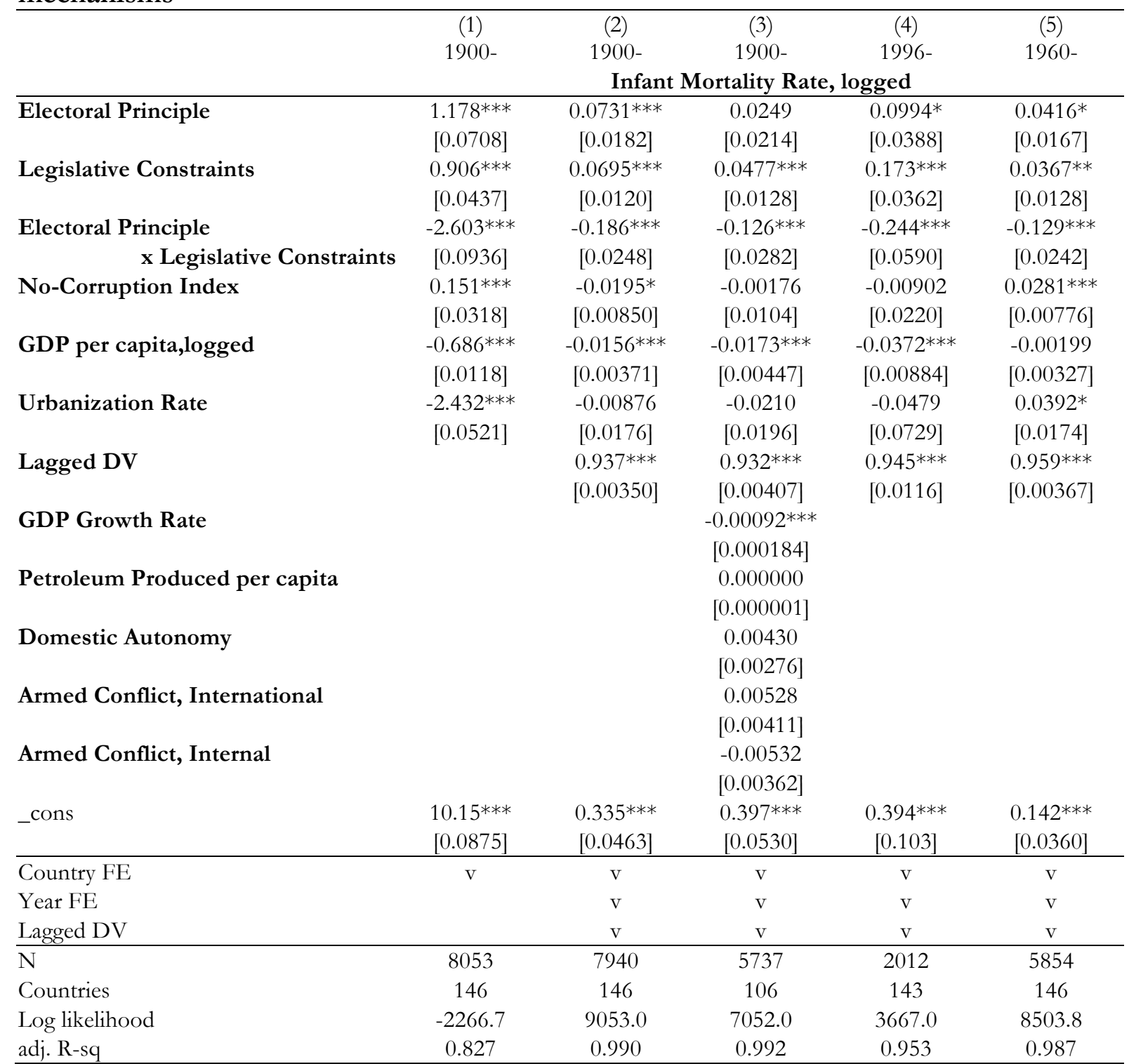

All independent variables are lagged for one year. Coefficients of yearly dummies are not reported. Standard error in brackets * $\mathrm{p}<0.05^{* *} \mathrm{p}<0.01 * * * \mathrm{p}<0.001$.

Models 1 to 3 cover all the time period 1900 - 2012, while model 4 and 5 are for subsamples of different time periods. Consistent with the expectation, the positive effects of electoral competition on population health are contingent on whether the legislature is capable to control the executive branch. If the power of legislatures is limited, the establishment of free and fair elections does not necessarily lead to the improvement of health. The effects of electoral accountability mechanisms are especially salient when legislatures are powerful. Based on model 1 , the effects of an increase of the electoral index on mortality rate turn to negative once the legislative constraint index reaches the level of 0.45 .

Similarly, the development of legislative power itself is not helpful for health. Both vertical and horizontal accountability mechanisms lead to the decline of mortality rates only when 
the other accountability mechanism is also present. The results also show that the contingent effects of both accountability mechanisms prevail in subsamples of different time periods and across different model specifications. Furthermore, the effects of the quality of government indicator become insignificant or positive on mortality rate.

\subsection{The Threshold Effects of Democracy}

Table 6. Regression estimates of the threshold effect of democracy on health

\begin{tabular}{|c|c|c|c|c|c|c|}
\hline & $\begin{array}{l}(1) \\
1900-\end{array}$ & $\begin{array}{l}(2) \\
1900-\end{array}$ & $\begin{array}{l}(3) \\
1900-\end{array}$ & $\begin{array}{l}(4) \\
1996-\end{array}$ & $\begin{array}{l}(5) \\
1960-\end{array}$ & $\begin{array}{l}(6) \\
1960-\end{array}$ \\
\hline & \multicolumn{5}{|c|}{ Infant Mortality Rate, logged } & $\begin{array}{l}\text { Mortality } \\
\text { Rate Under } \\
5\end{array}$ \\
\hline Electoral Principle & $\begin{array}{l}2.278^{* * *} \\
{[0.0872]}\end{array}$ & $\begin{array}{l}0.123 * * * \\
{[0.0237]}\end{array}$ & $\begin{array}{c}0.0405 \\
{[0.0269]}\end{array}$ & $\begin{array}{l}0.460^{*} \\
{[0.189]}\end{array}$ & $\begin{array}{c}1.260^{* * *} \\
{[0.125]}\end{array}$ & $\begin{array}{c}0.855^{* * *} \\
{[0.132]}\end{array}$ \\
\hline Electoral Principle^2 & $\begin{array}{c}-2.891 * * * \\
{[0.0869]}\end{array}$ & $\begin{array}{c}-0.172 * * * \\
{[0.0239]}\end{array}$ & $\begin{array}{c}-0.0959 * * * \\
{[0.0265]}\end{array}$ & $\begin{array}{l}-0.471^{*} \\
{[0.185]}\end{array}$ & $\begin{array}{c}-1.974 * * * \\
{[0.123]}\end{array}$ & $\begin{array}{c}-1.570^{* * *} \\
{[0.129]}\end{array}$ \\
\hline No-Corruption & $\begin{array}{l}0.279 * * * \\
{[0.0319]}\end{array}$ & $\begin{array}{c}-0.0138 \\
{[0.00862]}\end{array}$ & $\begin{array}{c}-0.000558 \\
{[0.0104]}\end{array}$ & $\begin{array}{l}-0.0909 \\
{[0.0630]}\end{array}$ & $\begin{array}{l}0.323 * * * \\
{[0.0366]}\end{array}$ & $\begin{array}{l}0.235^{* * *} \\
{[0.0397]}\end{array}$ \\
\hline GDP per capita,logged & $\begin{array}{c}-0.685^{* * *} \\
{[0.0113]}\end{array}$ & $\begin{array}{c}-0.0170^{* * *} \\
{[0.00371]}\end{array}$ & $\begin{array}{c}-0.0185^{* * *} \\
{[0.00448]}\end{array}$ & $\begin{array}{c}-0.691 * * * \\
{[0.0187]}\end{array}$ & $\begin{array}{c}-0.558^{* * *} \\
{[0.0137]}\end{array}$ & $\begin{array}{c}-0.577 * * * \\
{[0.0138]}\end{array}$ \\
\hline Urbanization Rate & $\begin{array}{c}-2.407 * * * \\
{[0.0511]}\end{array}$ & $\begin{array}{r}-0.00812 \\
{[0.0175]}\end{array}$ & $\begin{array}{l}-0.0195 \\
{[0.0196]}\end{array}$ & $\begin{array}{c}-3.455^{* * *} \\
{[0.163]}\end{array}$ & $\begin{array}{c}-2.628^{* * *} \\
{[0.0644]}\end{array}$ & $\begin{array}{c}-3.282^{* * *} \\
{[0.0670]}\end{array}$ \\
\hline Lagged DV & & $\begin{array}{l}0.935^{* * *} \\
{[0.00355]}\end{array}$ & $\begin{array}{l}0.931 * * * \\
{[0.00414]}\end{array}$ & & & \\
\hline GDP Growth Rate & & & $\begin{array}{c}-0.0009 * * * \\
{[0.00018]}\end{array}$ & & & \\
\hline $\begin{array}{l}\text { Petroleum Produced } \\
\text { per capita }\end{array}$ & & & $\begin{array}{l}0.0000003 \\
{[0.000001]}\end{array}$ & & & \\
\hline Domestic Autonomy & & & $\begin{array}{c}0.00421 \\
{[0.00274]}\end{array}$ & & & \\
\hline $\begin{array}{l}\text { Armed Conflict, } \\
\text { International } \\
\text { Armed Conflict, Internal }\end{array}$ & & & $\begin{array}{c}0.00564 \\
{[0.00410]} \\
-0.00532 \\
{[0.00362]}\end{array}$ & & & \\
\hline _cons & $\begin{array}{l}10.06^{* * *} \\
{[0.0830]}\end{array}$ & $\begin{array}{l}0.357 * * * \\
{[0.0462]} \\
\end{array}$ & $\begin{array}{l}0.415^{* * *} \\
{[0.0529]}\end{array}$ & $\begin{array}{c}10.65^{* * *} \\
{[0.145]}\end{array}$ & $\begin{array}{c}9.235^{* * *} \\
{[0.107]}\end{array}$ & $\begin{array}{c}10.12 * * * \\
{[0.111]}\end{array}$ \\
\hline Country FE & $\mathrm{V}$ & $\mathrm{V}$ & $\mathrm{V}$ & $\mathrm{V}$ & $\mathrm{V}$ & $\mathrm{V}$ \\
\hline $\begin{array}{l}\text { Year FE } \\
\text { Lagged DV }\end{array}$ & & $\begin{array}{l}\mathrm{V} \\
\mathrm{V}\end{array}$ & $\begin{array}{l}\mathrm{v} \\
\mathrm{v}\end{array}$ & & & \\
\hline $\mathrm{N}$ & 8055 & 7942 & 5739 & 2012 & 5870 & 5488 \\
\hline Countries & 146 & 146 & 106 & 143 & 146 & 146 \\
\hline Log likelihood & -2114.5 & 9053.7 & 7051.3 & 1507.7 & -981.4 & -591.2 \\
\hline adj. R-sq & 0.833 & 0.990 & 0.992 & 0.603 & 0.676 & 0.719 \\
\hline
\end{tabular}

To test the hypothesis that in transitional democracies, political competition does not necessarily lead to the provision of public goods (hypothesis 3), we include the squared term of the electoral principle index in the analysis. The results are shown in Table 6. Models 1 to 3 include observations from 1900 to 2012, and the other models are for subsamples of different time periods. 
Consistent with the hypothesis, the results suggest that there is a curvilinear relationship between democracy and health outcome. As the level of democracy increases, infant and child mortality rates first slightly increase and then decrease. The lines in Figure 6 represent the relationship between the electoral index and mortality rate estimated by model 1 , and the gray dots are the observed values of the two indicators. In quite close autocracies, a small increase in suffrage or political competition does not lead to the improvement of population health. Only when the level of democracy reaches certain threshold, mortality rate declines as democracy matures. Based on these models, the threshold is at a lower-middle level of the electoral index, which roughly represents a regime in which a small number of civil and political groups are independent of the ruling regime, freedom of discussion is somewhat respected, and elections allow for some competition. Once crossing the threshold, improved political participation and competition are leading to improved health.

Figure 6: The estimated relationship between democracy and morality rate

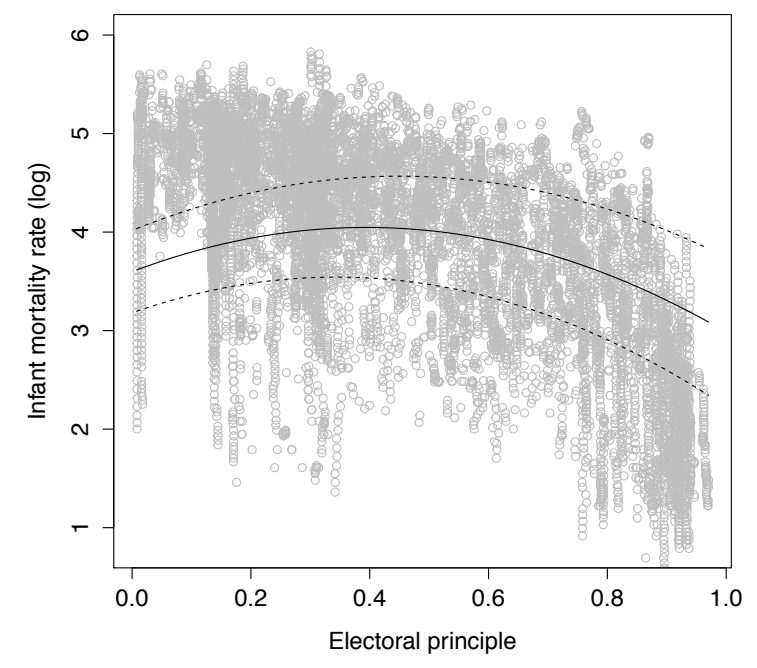

It has to be noted that this pattern holds even for the subsample of the most recent two decades. In addition, when the squared term of electoral principle is included in the model, the effects of the no corruption index disappear or remain negative on population health. Since there may be also a threshold effect of democracy on corruption, the relationship between democracy and governance and thus their potential joint impacts on public goods provision require further studies ${ }^{1}$.

\footnotetext{
${ }^{1}$ Norris (2012) has argued that high levels of electoral democracy and QoG converge, and that could be one reason why the effects of corruption on mortality rates seem to vary substantially across subsamples. Another interesting perspective worth investigating is the conditions under which corruption or clientelism can serve as substitute for social policies and can be used as a way to gain access to public services thus enhancing health outcomes.
} 


\section{Conclusions}

In this paper we conduct thorough analyses examining the effects of regime type and governance quality on the improvement of health outcomes in a country. By utilizing a dataset that covers more than 160 countries over the years 1900-2012 and contains nuanced and disaggregated measures of democracy and governance, we show that democracy has significant and positive effects on population health. Our analyses suggest that the mixed results pointed out in previous research are partly due to incomplete samples that do not reflect the entire variation range of combinations in terms of democratic development, governance performance and health outcomes. The previously widely used indicators of governance quality are only measured for the recent two decades, when the variations of the governance indicators across non-democracies are quite limited. Furthermore, we find that the positive force of democracy on health outcomes is clearer if the threshold effect of democracy is also taken into account. That is, after the transitional period of democratic reforms, mortality rate declines as democracy matures. Finally, the positive impacts of democracy are especially salient when both vertical and horizontal accountability mechanisms are present. The effects of the squared term of democracy indicators and the interaction between vertical and horizontal accountability indicators are significant and robust across models with different specifications and different time periods.

The findings have a number of implications. First, the results demonstrate the impact of incomplete samples, especially for topics affected by global temporal trends. Limited coverage of samples over time and across countries can be influential. For the topic of this paper, the important contribution of the V-Dem project is not in providing drastically different measures of regime types and governance quality, but in collecting a dataset that covers a long time period of most countries for various detailed indicators.

Second, the results show that the effects of corruption on mortality rates seem to vary substantially across samples of different time periods and models with different specifications. Further studies are required to examine whether the effects of governance quality are conditional on some factors sensitive to temporal patterns, whether the impacts of corrupt governance vary across democracies of different ages or different waves, and if other indicators on governance, such as state capacity or effectiveness, show the same pattern.

Finally, our findings highlight the importance of exploring the role of different dimensions of democracy. Scholars have pointed out the limitation of electoral competition. How different types of horizontal accountability mechanisms improve the provision of public goods or limit the distortion of resource allocation are worth further studies. 


\section{References}

Acemoglu, D., \& Simon Johnson. 2005. "Disease and Development: The Effect of Life Expectancy on Economic Growth." Unpublished Paper.

Acemoglu, D., \& Robinson, J. A. 2012. "Why Nations Fail: The Origins of Power, Prosperity, and Poverty". Crown.

Álvaro, F., Álvarez-Dardet, C., \& Teresa Ruiz, M. 2004. "Effect of Democracy on Health: Ecological Study“. BMJ 2004;329:1421.

Antonis, A., Delis M. D., \& Kammas, P. 2009. "Are Democratic Governments More Efficient?". Department of Economics, University Of Ioannina.

Besley T., \& Kudamatsu, M. 2006."Health and Democracy”. American Economic Review, 313318.

Biser, J., \& Edwards, J. 2012. "Civil Liberties and Access to Water: Analysis of 193 countries". Applied Econometrics and International Development, 12-1.

Brown, S. 2005. "Foreign Aid and Democracy Promotion: Lessons from Africa". The European Journal of Development Research, 17:2, 197-198.

Bueno de Mesquita, Bruce, Alastair Smith, Randolph M. Siverson, and James D. Morrow. 2005. The Logic of Political Survival. MIT Press.

Clio-Infra. Accessed May 27, 2014. http://www.clio-infra.eu/.

Coppedge , Michael and John Gerring, with David Altman, Michael Bernhard, Steven Fish, Allen Hicken, Matthew Kroenig, Staffan I. Lindberg, Kelly McMann, Pamela Paxton, Holli A. Semetko, Svend-Erik Skaaning, Jeffrey Staton, and Jan Teorell. 2011. "Conceptualizing and Measuring Democracy: A New Approach.” Perspectives on Politics 9(2), 247-267.

Coppedge, Michael, John Gerring, Staffan I. Lindberg, Jan Teorell, David Altman, Michael Bernhard, M. Steven Fish, Adam Glynn, Allen Hicken, Carl Henrik Knutsen, Kelly McMann, Daniel Pemstein, Svend-Erik Skaaning, Jeffrey Staton, Eitan Tzelgov, Yi-ting Wang, Brigitte Zimmerman. 2015a. "Varieties of Democracy Codebook v4". Varieties of Democracy Project: Project Documentation Paper Series.

Coppedge, Michael, John Gerring, Staffan I. Lindberg, Jan Teorell, David Altman, Michael Bernhard, M. Steven Fish, Adam Glynn, Allen Hicken, Carl Henrik Knutsen, Kelly McMann, Daniel Pemstein, Svend-Erik Skaaning, Jeffrey Staton, Eitan Tzelgov, Yi-ting Wang, Brigitte Zimmerman. 2015b. "Varieties of Democracy Dataset v. 4.2," Varieties of Democracy (VDem) Project.

Coppedge, Michael, John Gerring, Staffan I. Lindberg, Jan Teorell, David Altman, Michael Bernhard, M. Steven Fish, Adam Glynn, Allen Hicken, Carl Henrik Knutsen, Kelly McMann, 
Daniel Pemstein, Svend-Erik Skaaning, Jeffrey Staton, Eitan Tzelgov, Yi-ting Wang, and Brigitte Zimmerman. 2015c. "Varieties of Democracy: Methodology v4." Varieties of Democracy (V-Dem) Project.

Coppedge, Michael, John Gerring, Staffan I. Lindberg, Jan Teorell, Vlad Ciobanu. 2015d. "Varieties of Democracy: Country Coding Units v4." Varieties of Democracy Project: Project Documentation Paper Series.

Deacon, R., \& Saha, S. 2005. "Public Good Provision By Dictatorship: A Survey". Department Working Paper, Department of Economics, UCSB.

Diamond, L. 2002. “Thinking About Hybrid Regimes”. Journal of Democracy 13 (2): 21-35.

Diamond, L. 2007. “A Quarter-Century of Promoting Democracy”. Journal of Democracy 18:4, 118-120.

Gapminder. Accessed May 15, 2014. http://www.gapminder.org/data/.

Gauri, V., \& Khaleghian, P. 2002. "Immunization in

Developing Countries: Its Political and Organizational Determinants". World Development 30 (December): 2109-32.

Gerken, H. K. 2009. “The Democracy Index: Why Our Election System is Failing and How to Fix It". Princeton: Princeton University Press.

Gerring, J. 2001. "Social Science Methodology: A Criterial Framework". Cambridge University Press.

Gerring, J., Thacker, S. C., \& Alfaro R. 2012. “Democracy and Human Development”. Journal of Politics, 74:1 (January) 1-17.

Guilhot, N. 2005. "The Democracy Makers: Human Rights and International Order". Columbia University Press, 2005 - Political Science.

Harding, R., \& Wantchekon L. 2010. "The political economy of human development". Human Development Research Paper 2010:29".

Hafner-Burton, E., Hyde D. S., \& Jablonski, R. S. 2013. "When Do Governments Resort to Election Violence?”. British Journal of Political Science 44:149-179.

Holmberg, S. \& Rothstein, B. 2010. "Quality of Government Is Needed to Reduce Poverty and Economic Inequality". QoG Working paper series 2010:3. The Quality of Government Institute, University of Gothenburg.

D. Kaufmann, A. Kraay, and M. Mastruzzi. 2010. "The Worldwide Governance Indicators: a Summary of Methodology, Data and Analytical Issues”, World Bank Policy Research Working Paper, vol. 5430. 
Keefer P., \& Vlaicu, R. 2004. "Democracy, Credibility and Clientelism”, World Bank Policy Research Working Paper 3472.

Keefer, P. 2005. "Democratization and Clientelism: Why are Young

Democracies Badly Governed?”, World Bank Policy Research Working Paper 3594.

Klomp, J., \& de Haan, J. 2009. "Is the Political System Really Related to Health?”, Social Science and Medicine 69:1, 36-46.

Kudamatsu, M. 2012. "Has Democratization Reduced Infant Mortality in Sub-Saharan Africa? Evidence from micro data". Journal of the European Economic Association 10:6, 1294-1317.

Lewis, M. 2006. "Governance and Corruption in the Public Health Sector". Working Paper 78. Washington D. C.: Center for Global Development.

Lindberg, S. I. 2006. "Democracy and Elections in Africa". Baltimore: Johns Hopkins University Press.

Lindberg, S. I. 2009. "Democratization by Elections: A Mixed Record". Journal of Democracy 20(3): 86-92.

Lindberg, S. I. 2013. "Mapping accountability: core concept and subtypes”. International Review of Administrative Sciences, (June) 79: 2, 202-226

Marshall, M. G., \& Jaggers K. 2013. "Polity IV Project: Political Regime Characteristics and Transitions, 1800-2006."

McGuire, J. W. 2004. "Democracy, Health Care, and Under-5 Mortality: A Cross-National Study of Developing Countries". Wesleyan University. Unpublished manuscript.

McMann, K., Teorell J., and Zimmerman, B. 2015. "How Do I Know Whether My Data Are Valid? Assessing the Validity of V-Dem Corruption Measures". V-Dem working paper series.

McFaul, M. 2004. 'Democracy Promotion As a World Value". The Washington Quarterly, 8:1, $147-163$.

Norris, P. 2012. "Making Democratic Governance Work: How Regimes Shape Prosperity, Welfare, and Peace”. Cambridge: Cambridge University Press.

O’Donnell, G. 1998. "Horizontal accountability in new democracies". Journal of Democracy 9(3): $112-126$.

Pemstein, Dan, Eitan Tzelgov, and Yi-ting Wang. 2015. "Evaluating and Improving Item Response Theory Models for Cross-National Expert Surveys". Varieties of Democracy Institute: Working Paper No. 1.

Ross, M. 2006. "Is Democracy Good for the Poor?". American Journal of Political Science 50 (October): 860-74. 
Rothstein, B., \& Teorell, J. 2008. "What is Quality of Government? A Theory of Impartial Government Institutions", Governance: An International Journal of Policy, Administration, and Institutions 21:2, 165-190.

Rothstein, B. 2011. "'The Quality of Government: Corruption, Social Trust, and Inequality in International Perspective", University of Chicago Press, Chicago.

Sacks, A., \& Levi, M. 2007. "Measuring Government Effectiveness and its Consequences for Social Welfare”. Department of Sociology, University of Washington.

Stokes, S., Przeworski, A., Bernard M. 1999. "Democracy, Accountability, and Representation”, Cambridge University Press.

Shandra, J. M., Nobles, J., London, B., \& Williamson, J. B. 2004. "Dependency, Democracy, and Infant Mortality: A Quantitative, Cross-National Analysis of Less Developed Countries." Social Science and Medicine 59 (July): 321-33.

Schmitter, P. C. 2004. "The ambiguous virtues of accountability". Journal of Democracy 15(4): $47-60$

Schedler, A. 2002. "The Menu of Manipulation". Journal of Democracy 13 (2): 36-50.

Transparency International. 2013. Corruption Perceptions Index.

Treisman, D. 2007. "What Have We Learned About the Causes of Corruption from Ten Years of Cross-National Empirical Research?”. Annual Review of Political Science, 10:211, 244.

Vollmer, S. \& Ziegler, M. 2009. "Political Institutions and Human Development - Does Democracy Fulfil Its 'Constructive' and 'Instrumental' Role?". World Bank Policy Research Working Paper No. 4828.

UN Inter-Agency Group for Child Mortality Estimation (IGME). 2004. Child Mortality Estimates. UN: New York. Available at www.childmortality.org/

World Bank Institute, 2005. "Social Accountability in the Public Sector". Washington DC: WBI Working Paper No.33641. 


\section{Appendix}

\section{Table A.1. Independent Variables for the V-Dem Project}

\begin{tabular}{|c|c|c|}
\hline Indicator & Question & Response categories / Aggregation \\
\hline Electoral component index & $\begin{array}{l}\text { To what extent is the electoral principle of democracy achieved? } \\
\text { Clarification: The electoral principle of democracy seeks to achieve } \\
\text { responsiveness and accountability between leaders and citizens through the } \\
\text { mechanism of competitive elections. This is presumed to be achieved when } \\
\text { suffrage is extensive; political and civil society organizations can operate } \\
\text { freely; elections are clean and not marred by fraud or systematic } \\
\text { irregularities; and the chief executive of a country is selected (directly or } \\
\text { indirectly) through elections. }\end{array}$ & 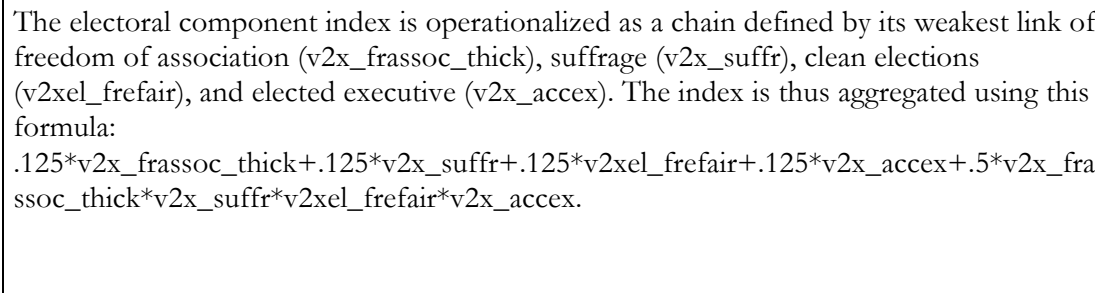 \\
\hline $\begin{array}{l}\text { Legislative constraints on the } \\
\text { executive index }\end{array}$ & $\begin{array}{l}\text { To what extent is the legislature and government agencies (e.g., comptroller } \\
\text { general, general prosecutor, or ombudsman) capable of questioning, } \\
\text { investigating, and exercising oversight over the executive? }\end{array}$ & $\begin{array}{l}\text { The index is formed by taking the point estimates from a Bayesian factor analysis model } \\
\text { of the indicators for legislature questions officials in practice (v2lgqstexp), executive } \\
\text { oversight (v2lgotovst), legislature investigates in practice (v2lginvstp), and legislature } \\
\text { opposition parties (v2lgoppart). }\end{array}$ \\
\hline $\begin{array}{l}\text { Executive bribery and corrupt } \\
\text { exchanges }\end{array}$ & $\begin{array}{l}\text { How routinely do members of the executive (the head of state, the head of } \\
\text { government, and cabinet ministers), or their agents, grant favors in } \\
\text { exchange for bribes, kickbacks, or other material inducements? }\end{array}$ & $\begin{array}{l}\text { 0: It is routine and expected. } \\
\text { 1: It happens more often than not in dealings with the executive. } \\
\text { 2: It happens but is unpredictable: those dealing with the executive find it hard to predict } \\
\text { when an inducement will be necessary. } \\
\text { 3: It happens occasionally but is not expected. } \\
\text { 4: It never, or hardly ever, happens. }\end{array}$ \\
\hline $\begin{array}{l}\text { Executive embezzlement and } \\
\text { theft }\end{array}$ & $\begin{array}{l}\text { How often do members of the executive (the head of state, the head of } \\
\text { government, and cabinet ministers), or their agents, steal, embezzle, or } \\
\text { misappropriate public funds or other state resources for personal or family } \\
\text { use? }\end{array}$ & $\begin{array}{l}\text { 0: Constantly. Members of the executive act as though all public resources were their } \\
\text { personal or family property. } \\
\text { 1: Often. Members of the executive are responsible stewards of selected public resources } \\
\text { but treat the rest like personal property. } \\
\text { 2: About half the time. Members of the executive are about as likely to be responsible } \\
\text { stewards of selected public resources as they are to treat them like personal property. } \\
\text { 3: Occasionally. Members of the executive are responsible stewards of most public } \\
\text { resources but treat selected others like personal property. } \\
\text { 4: Never, or hardly ever. Members of the executive are almost always responsible } \\
\text { stewards of public resources and keep them separate from personal or family property. }\end{array}$ \\
\hline
\end{tabular}


Public sector corrupt exchanges $\quad$ How routinely do public sector employees grant favors in exchange for bribes, kickbacks, or other material inducements?

Legislature corrupt activities

Judicial corruption decision

payments or bribes in order to speed up or delay the process or to obtain

favorable judicial decision?

Is the state autonomous from the control of other states with respect to the conduct of domestic policy?
How often do individuals or businesses make undocumented extra

0 : Extremely common. Most public sector employees are systematically involved in petty but corrupt exchanges almost all the time.

1: Common. Such petty but corrupt exchanges occur regularly involving a majority of

public employees.

2: Sometimes. About half or less than half of public sector employees engage in such exchanges for petty gains at times.

3: Scattered. A small minority of public sector employees engage in petty corruption from time to time.

4: No. Never, or hardly ever.

0: Commonly. Most legislators probably engage in these activities.

1: Often. Many legislators probably engage in these activities.

2: Sometimes. Some legislators probably engage in these activities.

3: Very occasionally. There may be a few legislators who engage in these activities but the vast majority do not.

4: Never, or hardly ever.

\section{0: Always.}

1. Usually.

2. About half of the time.

3: Not usually

4: Never.
0: Non-autonomous. National level authority is exercised by an external power, either by law or in practice.

1: Semi-autonomous. An external political actor directly constrains the ability of

domestic actors to rule, decides who can or cannot rule through formal rules or informal understandings, or precludes certain policies through explicit treaty provisions or well-

understood rules of the game from which the subject state cannot withdraw.

2: Autonomous. Domestic political actors exercise political authority free of the direct control of external political actors. 
Table A.2. Structure of aggregation for the main independent variables

\begin{tabular}{|c|c|c|c|}
\hline $\begin{array}{l}\text { Mid-Level Democracy } \\
\text { and Governance Indices }\end{array}$ & Lower-Level Indices & Names Indicators & $\begin{array}{l}\text { v2_tag Indices and } \\
\text { Indicators }\end{array}$ \\
\hline \multirow[t]{32}{*}{ Electoral Component Index } & & & v2x_EDcomp_thick \\
\hline & $\begin{array}{l}\text { Freedom of association } \\
\text { index (thick) }\end{array}$ & & v2x_frassoc_thick \\
\hline & & Party Ban & v2psparban \\
\hline & & Barriers to parties & v2psbars \\
\hline & & Opposition parties autonomy & v2psoppaut \\
\hline & & Elections multiparty & v2elmulpar \\
\hline & & CSO entry and exit & v2cseeorgs \\
\hline & & CSO repression & v2csreprss \\
\hline & $\begin{array}{l}\text { Share of population with } \\
\text { suffrage }\end{array}$ & & v2x_suffr \\
\hline & & Percent of population with suffrage & v2elsuffrage \\
\hline & Clean elections index & & v2xel_frefair \\
\hline & & EMB autonomy & v2elembaut \\
\hline & & EMB capacity & v2elembcap \\
\hline & & Election voter registry & v2elrgstry \\
\hline & & Election vote buying & v2elvotbuy \\
\hline & & Election other voting irregularities & v2elirreg \\
\hline & & Election government intimidation & v2elintim \\
\hline & & Election other electoral violence & v2elpeace \\
\hline & & Election free and fair & v2elfrfair \\
\hline & $\begin{array}{l}\text { Elected executive index (de } \\
\text { jure) }\end{array}$ & & v2x_accex \\
\hline & & Lower chamber elected & v2lgello \\
\hline & & Upper chamber elected & v2lgelecup \\
\hline & & Legislature dominant chamber & v2lgdomchm \\
\hline & & $\begin{array}{l}\text { HOS selection by legislature in } \\
\text { practice }\end{array}$ & v2exaphos \\
\hline & & HOS appointment in practice & v2expathhs \\
\hline & & $\begin{array}{l}\text { HOG selection by legislature in } \\
\text { practice }\end{array}$ & v2exaphogp \\
\hline & & HOG appointment in practice & v2expathhg \\
\hline & & HOS appoints cabinet in practice & v2exdfcbhs \\
\hline & & HOG appoints cabinet in practice & v2exdjcbhg \\
\hline & & HOS dismisses ministers in practice & v2exdfdmhs \\
\hline & & $\begin{array}{l}\text { HOG dismisses ministers in } \\
\text { practice }\end{array}$ & v2exdfdshg \\
\hline & & HOS appoints cabinet in practice & v2exdfcbhs \\
\hline
\end{tabular}

\begin{tabular}{|l|l|l|}
\hline $\begin{array}{l}\text { Legislative constraints on } \\
\text { the executive index }\end{array}$ & v2xlg_legcon \\
\cline { 1 - 2 } & $\begin{array}{l}\text { Legislature questions officials in } \\
\text { practice }\end{array}$ & v2lgqstexp \\
\hline & $\begin{array}{l}\text { Executive oversight } \\
\text { Legislature investigates in practice }\end{array}$ & v2lgotovst \\
\hline & Legislature opposition parties & v2lgoppart \\
\hline
\end{tabular}

\begin{tabular}{|l|l|l|}
\hline No-corruption index & v2exbribe \\
\hline & $\begin{array}{l}\text { Executive bribery and corrupt } \\
\text { exchanges }\end{array}$ & vexembez \\
\hline & $\begin{array}{l}\text { Executive embezzlement and theft } \\
\text { Public sector corrupt exchanges }\end{array}$ & v2excrptps \\
\hline & $\begin{array}{l}\text { Legislature corrupt activities } \\
\text { Judicial corruption decision }\end{array}$ & $\begin{array}{l}\text { v2lgcrrpt } \\
\text { v2jucorrdc }\end{array}$ \\
\hline
\end{tabular}


Table A.3. Descriptive statistics of all variables used in the analysis

\begin{tabular}{lrrrr}
\hline Indicators & Mean & SD & \multicolumn{1}{c}{ Min } & Max \\
\hline Infant Mortality Rate (log) & 3.85 & 1.04 & 0.00 & 5.83 \\
Mortality Rate Under 5 (log) & 3.88 & 1.19 & 1.06 & 6.09 \\
Electoral Principle of Democracy & 0.50 & 0.27 & 0.01 & 0.97 \\
Legislative Constraints & 0.53 & 0.32 & 0.03 & 0.99 \\
Polity & 1.63 & 7.45 & -10.00 & 10.00 \\
No-Corruption & 0.50 & 0.32 & 0.02 & 0.99 \\
TI Corruption Perceptions Index & 4.33 & 2.26 & 0.40 & 10.00 \\
WB Rule of Law & -0.15 & 1.00 & -2.67 & 2.00 \\
WB Government Effectiveness & -0.06 & 1.00 & -2.45 & 2.34 \\
GDP per capita (log) & 7.99 & 1.03 & 5.35 & 10.67 \\
Urbanization Rate & 0.46 & 0.23 & 0.01 & 0.97 \\
GDP Growth Rate & 1.94 & 5.90 & -61.49 & 65.90 \\
Petroleum Produced per capita & 319.80 & 2359.69 & 0.00 & 78588.80 \\
Domestic Autonomy & 0.81 & 0.72 & -1.90 & 1.94 \\
Armed Conflict, International & 0.08 & 0.27 & 0.00 & 1.00 \\
Armed Conflict, Internal & 0.12 & 0.32 & 0.00 & 1.00 \\
\hline
\end{tabular}

Table A.4. Robustness Tests

\begin{tabular}{|c|c|c|c|c|c|c|}
\hline \multirow[b]{2}{*}{ DV } & (1) & (2) & (3) & (4) & (5) & (6) \\
\hline & \multicolumn{6}{|c|}{ Infant Mortality Rate (log) } \\
\hline & & & Random & & & \\
\hline Model & OLS & OLS & Effect & Fixed Effect & Fixed Effect & Poisson \\
\hline Sample & Full & Full & Full & Full & Imputed & Imputed \\
\hline \multirow{2}{*}{ Electoral Principle } & $-54.11 * * *$ & $-21.74 * * *$ & $-0.0348^{* * *}$ & & $-0.146^{* * *}$ & $-0.360 * * *$ \\
\hline & [1.972] & [1.925] & {$[0.00636]$} & & {$[0.0187]$} & {$[0.00577]$} \\
\hline \multirow[t]{2}{*}{ No-Corruption } & $34.81 * * *$ & $-8.530 * * *$ & $-0.0208^{* *}$ & & $-0.113^{* * *}$ & $-0.0679 * * *$ \\
\hline & {$[1.525]$} & [1.684] & {$[0.00643]$} & & {$[0.0203]$} & {$[0.00525]$} \\
\hline \multirow{2}{*}{$\begin{array}{l}\text { Electoral Principle } \\
\qquad(10 \text { yr lagged })\end{array}$} & & & & $-0.522 * * *$ & & \\
\hline & & & & {$[0.0290]$} & & \\
\hline \multicolumn{2}{|l|}{ No-Corruption } & & & 0.0191 & & \\
\hline & & & & {$[0.0345]$} & & \\
\hline \multirow{2}{*}{ GDP per capita (log) } & $-24.15^{* * *}$ & $-13.38^{* * *}$ & $-0.0222 * * *$ & $-0.782^{* * *}$ & $-0.214 * * *$ & $-0.196 * * *$ \\
\hline & {$[0.707]$} & [0.683] & {$[0.00284]$} & {$[0.0124]$} & {$[0.00787]$} & [0.00189] \\
\hline \multirow[t]{2}{*}{ Urbanization Rate } & $-59.88 * * *$ & $-44.60 * * *$ & $-0.0329 * *$ & $-2.511 * * *$ & $-0.938 * * *$ & $-2.317 * * *$ \\
\hline & [2.900] & [2.695] & {$[0.0104]$} & {$[0.0556]$} & [0.0417] & {$[0.0121]$} \\
\hline \multirow[t]{2}{*}{ _cons } & $301.4^{* * *}$ & $308.1 * * *$ & $0.256^{* * *}$ & $11.46^{* * *}$ & $4.479 * * *$ & \\
\hline & [4.355] & [11.68] & [0.0407] & [0.0809] & {$[0.0800]$} & \\
\hline Year FE & & $\mathrm{V}$ & $\mathrm{V}$ & $\mathrm{V}$ & $\mathrm{V}$ & $\mathrm{v}$ \\
\hline Country FE & & & & $\mathrm{v}$ & $\mathrm{v}$ & $\mathrm{v}$ \\
\hline Region FE & & $\mathrm{v}$ & & & & \\
\hline Lagged DV & & & $\mathrm{v}$ & & $\mathrm{V}$ & $\mathrm{V}$ \\
\hline $\mathrm{N}$ & 8014 & 8014 & 7942 & 7291 & 19213 & 19213 \\
\hline adj. R-sq & 0.592 & 0.727 & 0.989 & 0.809 & 0.846 & \\
\hline Countries & & & 146 & 146 & 202 & 202 \\
\hline Log Likelihood & -39855.4 & -38189.9 & & -2155.6 & -6757.5 & -291022.5 \\
\hline
\end{tabular}


Table A.5. Country-years included in Table 2, Table 3, and the Imputed Data

\begin{tabular}{|c|c|c|c|c|}
\hline \multicolumn{2}{|r|}{ Country_name } & \multirow{2}{*}{$\frac{\text { Year range Table } 2}{1996-2000}$} & \multirow{2}{*}{$\frac{\text { Year range Table } \mathbf{3}}{1959-2008}$} & \multirow{2}{*}{$\frac{\text { Imputed Data }}{1900-2012}$} \\
\hline 1 & Afghanistan & & & \\
\hline 2 & Albania & $1996-2010$ & $1958-2010$ & $1912-2012$ \\
\hline 3 & Algeria & $1996-2010$ & $1953-2010$ & $1900-2012$ \\
\hline 4 & Angola & $1996-2010$ & $1973-2010$ & $1900-2012$ \\
\hline 5 & Argentina & $1996-2010$ & $1946-2010$ & $1900-2012$ \\
\hline 6 & Armenia & $1996-2010$ & $1990-2010$ & $1990-2012$ \\
\hline 7 & Australia & $1996-2010$ & $1902-2010$ & $1901-2012$ \\
\hline 8 & Austria & $1996-2010$ & $1919-2010$ & $1918-2012$ \\
\hline 9 & Azerbaijan & $1996-2010$ & $1990-2010$ & $1990-2012$ \\
\hline 10 & Bahrain & $1996-2010$ & - & - \\
\hline 11 & Bangladesh & $1996-2010$ & $1973-2010$ & $1971-2012$ \\
\hline 12 & Barbados & - & - & $1900-2012$ \\
\hline 13 & Belarus & $1996-2010$ & $1990-2010$ & $1990-2012$ \\
\hline 14 & Belgium & $1996-2010$ & $1900-2010$ & $1900-2012$ \\
\hline 15 & Benin & $1996-2008$ & $1959-2008$ & $1900-2012$ \\
\hline 16 & Bhutan & - & - & $1900-2012$ \\
\hline 17 & Bolivia & $1996-2010$ & $1945-2010$ & $1900-2012$ \\
\hline 18 & Bosnia and Herzegovina & - & $1997-2010$ & $1992-2012$ \\
\hline 19 & Botswana & $1996-2008$ & $1961-2008$ & $1900-2012$ \\
\hline 20 & Brazil & $1996-2010$ & $1929-2010$ & $1900-2012$ \\
\hline 21 & Bulgaria & $1996-2010$ & $1905-2010$ & $1900-2012$ \\
\hline 22 & Burkina Faso & $1996-2010$ & $1959-2010$ & $1919-2012$ \\
\hline 23 & Burma/Myanmar & $1996-2010$ & $1931-1987$ & $1900-2012$ \\
\hline 24 & Burundi & $1996-2008$ & $1961-2008$ & $1916-2012$ \\
\hline 25 & Cambodia & $1996-2010$ & $1974-2010$ & $1900-2012$ \\
\hline 26 & Cameroon & $1996-2010$ & $1964-2010$ & $1961-2012$ \\
\hline 27 & Canada & $1996-2010$ & $1900-2010$ & $1900-2012$ \\
\hline 28 & Cape Verde & $1996-2008$ & $1973-2008$ & $1900-2012$ \\
\hline 29 & Central African Republic & $1996-2008$ & $1950-2008$ & $1920-2012$ \\
\hline 30 & Chad & $1996-2008$ & $1959-2008$ & $1920-2012$ \\
\hline 31 & Chile & $1996-2010$ & $1900-2010$ & $1900-2012$ \\
\hline 32 & China & $1996-2010$ & $1950-2010$ & $1900-2012$ \\
\hline 33 & Colombia & $1996-2010$ & $1923-2010$ & $1900-2012$ \\
\hline 34 & Comoros & $1996-2008$ & $1972-2008$ & $1900-2012$ \\
\hline & Congo, Democratic & & & \\
\hline 35 & Republic of & $1996-2010$ & $1960-2010$ & $1900-2012$ \\
\hline 36 & Congo, Republic of the & $1996-2008$ & $1960-2008$ & $1903-2012$ \\
\hline 37 & Costa Rica & $1996-2010$ & $1954-2010$ & $1900-2012$ \\
\hline 38 & Croatia & $1996-2010$ & $1991-2010$ & $1941-2012$ \\
\hline 39 & Cuba & $1996-2008$ & $1931-2008$ & $1902-2012$ \\
\hline 40 & Cyprus & - & - & $1900-2012$ \\
\hline 41 & Czech Republic & $1996-2010$ & $1929-2010$ & $1918-2012$ \\
\hline 42 & Denmark & $1996-2010$ & $1901-2010$ & $1900-2012$ \\
\hline 43 & Djibouti & $1996-2008$ & $1975-2008$ & $1900-2012$ \\
\hline 44 & Dominican Republic & $1996-2010$ & $1950-2010$ & $1900-2012$ \\
\hline 45 & East Timor & - & - & $1900-2012$ \\
\hline 46 & Ecuador & $1996-2010$ & $1900-2010$ & $1900-2012$ \\
\hline 47 & Egypt & $1996-2010$ & $1913-2010$ & $1900-2012$ \\
\hline 48 & El Salvador & $1996-2008$ & $1939-2008$ & $1900-2012$ \\
\hline 49 & Equatorial Guinea & $1996-2008$ & - & - \\
\hline 50 & Eritrea & - & $1993-1993$ & $1900-2012$ \\
\hline 51 & Estonia & $1996-2010$ & $1990-2010$ & $1918-2012$ \\
\hline 52 & Ethiopia & - & - & $1900-2012$ \\
\hline 53 & Fiji & - & - & $1900-2012$ \\
\hline 54 & Finland & $1996-2010$ & $1907-2010$ & $1900-2012$ \\
\hline 55 & France & $1996-2010$ & $1902-2010$ & $1900-2012$ \\
\hline 56 & Gabon & $1996-2008$ & $1959-2008$ & $1910-2012$ \\
\hline 57 & Gambia & $1996-2008$ & $1955-2008$ & $1900-2012$ \\
\hline 58 & Georgia & $1996-2010$ & $1990-2010$ & $1990-2012$ \\
\hline
\end{tabular}


German Democratic

\begin{tabular}{|c|c|c|c|c|}
\hline 59 & Republic & - & - & $1946-1990$ \\
\hline 60 & Germany & $1996-2010$ & $1903-2010$ & $1900-2012$ \\
\hline 61 & Ghana & $1996-2010$ & $1951-2010$ & $1902-2012$ \\
\hline 62 & Greece & $1996-2010$ & $1920-2010$ & $1900-2012$ \\
\hline 63 & Guatemala & $1996-2010$ & $1956-2010$ & $1900-2012$ \\
\hline 64 & Guinea & $1996-2008$ & $1950-2008$ & $1900-2012$ \\
\hline 65 & Guinea-Bissau & $1996-2008$ & $1975-2007$ & $1900-2012$ \\
\hline 66 & Guyana & - & - & $1900-2012$ \\
\hline 67 & Haiti & $1996-2008$ & $1955-2008$ & $1900-2012$ \\
\hline 68 & Honduras & $1996-2008$ & $1920-2008$ & $1900-2012$ \\
\hline 69 & Hong Kong & - & - & $1900-2010$ \\
\hline 70 & Hungary & $1996-2010$ & $1920-2010$ & $1918-2012$ \\
\hline 71 & Iceland & - & - & $1900-2012$ \\
\hline 72 & India & $1996-2010$ & $1910-2010$ & $1900-2012$ \\
\hline 73 & Indonesia & $1996-2010$ & $1949-2010$ & $1900-2012$ \\
\hline 74 & Iran & $1996-2010$ & $1950-2010$ & $1900-2012$ \\
\hline 75 & Iraq & $1996-2010$ & $1950-2010$ & $1920-2012$ \\
\hline 76 & Ireland & $1996-2010$ & $1921-2010$ & $1919-2012$ \\
\hline 77 & Israel & $1996-2010$ & $1950-2010$ & $1948-2012$ \\
\hline 78 & Italy & $1996-2010$ & $1900-2010$ & $1900-2012$ \\
\hline 79 & Ivory Coast & $1996-2010$ & $1955-2010$ & $1900-2012$ \\
\hline 80 & Jamaica & $1996-2010$ & $1913-2010$ & $1900-2012$ \\
\hline 81 & Japan & $1996-2010$ & $1946-2010$ & $1900-2012$ \\
\hline 82 & Jordan & $1996-2010$ & $1950-2010$ & $1922-2012$ \\
\hline 83 & Kazakhstan & $1996-2010$ & $1991-2010$ & $1990-2012$ \\
\hline 84 & Kenya & $1996-2010$ & $1950-2010$ & $1900-2012$ \\
\hline 85 & Korea, North & $1996-2008$ & $1959-2008$ & $1900-2012$ \\
\hline 86 & Korea, South & $1996-2010$ & $1950-2010$ & $1900-2012$ \\
\hline 87 & Kosovo & - & - & $1999-2012$ \\
\hline 88 & Kuwait & $1996-2010$ & - & $1900-2012$ \\
\hline 89 & Kyrgyzstan & $1996-2010$ & $1990-2010$ & $1990-2012$ \\
\hline 90 & Laos & $1996-2008$ & $1950-2008$ & $1900-2012$ \\
\hline 91 & Latvia & $1996-2010$ & $1990-2010$ & $1920-2012$ \\
\hline 92 & Lebanon & $2005-2008$ & $1955-2008$ & $1918-2012$ \\
\hline 93 & Lesotho & $1996-2008$ & $1950-2008$ & $1900-2012$ \\
\hline 94 & Liberia & $1996-2008$ & $1950-2008$ & $1900-2012$ \\
\hline 95 & Libya & $1996-2008$ & $1957-2008$ & $1934-2012$ \\
\hline 96 & Lithuania & $1996-2010$ & $1990-2010$ & $1918-2012$ \\
\hline 97 & Macedonia & $1996-2010$ & $1991-2010$ & $1991-2012$ \\
\hline 98 & Madagascar & $1996-2010$ & $1959-2009$ & $1900-2012$ \\
\hline 99 & Malawi & $1996-2010$ & $1954-2010$ & $1900-2012$ \\
\hline 100 & Malaysia & $1996-2010$ & $1955-2010$ & $1900-2012$ \\
\hline 101 & Maldives & - & - & $1900-2012$ \\
\hline 102 & Mali & $1996-2010$ & $1959-2010$ & $1900-2012$ \\
\hline 103 & Malta & - & - & $1900-2012$ \\
\hline 104 & Mauritania & $1996-2008$ & $1950-2008$ & $1904-2012$ \\
\hline 105 & Mauritius & - & - & $1900-2012$ \\
\hline 106 & Mexico & $1996-2010$ & $1949-2010$ & $1900-2012$ \\
\hline 107 & Moldova & $1996-2010$ & $1990-2010$ & $1990-2012$ \\
\hline 108 & Mongolia & $1996-2008$ & $1950-2008$ & $1911-2012$ \\
\hline 109 & Montenegro & - & - & $1900-2012$ \\
\hline 110 & Morocco & $1996-2010$ & $1962-2010$ & $1912-2012$ \\
\hline 111 & Mozambique & $1996-2010$ & $1973-2010$ & $1900-2012$ \\
\hline 112 & Namibia & $1996-2008$ & $1959-2008$ & $1900-2012$ \\
\hline 113 & Nepal & $1996-2008$ & $1959-2008$ & $1900-2012$ \\
\hline 114 & Netherlands & $1996-2010$ & $1901-2010$ & $1900-2012$ \\
\hline 115 & New Zealand & $1996-2010$ & $1902-2010$ & $1900-2012$ \\
\hline 116 & Nicaragua & $1996-2008$ & $1920-2008$ & $1900-2012$ \\
\hline 117 & Niger & $1996-2010$ & $1956-2010$ & $1922-2012$ \\
\hline 118 & Nigeria & $1996-2010$ & $1950-2010$ & $1914-2012$ \\
\hline 119 & Norway & $1996-2010$ & $1900-2010$ & $1900-2012$ \\
\hline
\end{tabular}




\begin{tabular}{|c|c|c|c|c|}
\hline 120 & Oman & $1996-2010$ & - & - \\
\hline 121 & Pakistan & $1996-2010$ & $1950-2010$ & $1947-2012$ \\
\hline 122 & Palestine/British Mandate & - & - & $1918-1947$ \\
\hline 123 & Palestine/Gaza & - & - & $1948-2012$ \\
\hline 124 & Palestine/West Bank & - & - & $1948-2012$ \\
\hline 125 & Panama & $1996-2008$ & $1949-2008$ & $1903-2012$ \\
\hline 126 & Papua New Guinea & - & - & $1900-2012$ \\
\hline 127 & Paraguay & $1996-2008$ & $1950-2008$ & $1900-2012$ \\
\hline 128 & Peru & $1996-2010$ & $1929-2010$ & $1900-2012$ \\
\hline 129 & Philippines & $1996-2010$ & $1907-2010$ & $1900-2012$ \\
\hline 130 & Poland & $1996-2010$ & $1929-2010$ & $1918-2012$ \\
\hline 131 & Portugal & $1996-2010$ & $1909-2010$ & $1900-2012$ \\
\hline 132 & Qatar & $1996-2010$ & $1971-2010$ & $1900-2012$ \\
\hline 133 & Romania & $1996-2010$ & $1910-2010$ & $1900-2012$ \\
\hline 134 & Russia & $1996-2010$ & $1906-2010$ & $1900-2012$ \\
\hline 135 & Rwanda & $1996-2008$ & $1961-2008$ & $1916-2012$ \\
\hline 136 & Sao Tome and Principe & - & $1975-2008$ & $1900-2012$ \\
\hline 137 & Saudi Arabia & $1996-2010$ & $1950-2010$ & $1932-2012$ \\
\hline 138 & Senegal & $1996-2010$ & $1957-2010$ & $1904-2012$ \\
\hline 139 & Serbia & - & - & $1900-2012$ \\
\hline 140 & Seychelles & - & $1967-2008$ & $1903-2012$ \\
\hline 141 & Sierra Leone & $1996-2008$ & $1954-2008$ & $1900-2012$ \\
\hline 142 & Singapore & $1996-2010$ & - & $1900-2012$ \\
\hline 143 & Slovakia & $1996-2010$ & $1993-2010$ & $1939-2012$ \\
\hline 144 & Slovenia & $1996-2010$ & $1989-2010$ & $1989-2012$ \\
\hline 145 & Solomon Islands & - & - & $1900-2012$ \\
\hline 146 & Somalia & $1996-2008$ & $1980-2008$ & $1900-2012$ \\
\hline 147 & Somaliland & - & - & $1900-2012$ \\
\hline 148 & South Africa & $1996-2010$ & $1910-2010$ & $1900-2012$ \\
\hline 149 & South Sudan & - & - & $2011-2012$ \\
\hline 150 & South Yemen & - & - & $1900-1990$ \\
\hline 151 & Spain & $1996-2010$ & $1901-2010$ & $1900-2012$ \\
\hline 152 & Sri Lanka & $1996-2010$ & $1948-2010$ & $1900-2012$ \\
\hline 153 & Sudan & - & - & $1900-2012$ \\
\hline 154 & Suriname & - & - & $1900-2012$ \\
\hline 155 & Swaziland & $1996-2008$ & $1964-2008$ & $1900-2012$ \\
\hline 156 & Sweden & $1996-2010$ & $1902-2010$ & $1900-2012$ \\
\hline 157 & Switzerland & $1996-2010$ & $1902-2010$ & $1900-2012$ \\
\hline 158 & Syria & $1996-2010$ & $1950-1964$ & $1918-2012$ \\
\hline 159 & Taiwan & $1996-2008$ & $1950-2008$ & $1900-2012$ \\
\hline 160 & Tajikistan & $1996-2010$ & $1990-2010$ & $1990-2012$ \\
\hline 161 & Tanzania & $1996-2010$ & $1950-2010$ & $1914-2012$ \\
\hline 162 & Thailand & $1996-2010$ & $1950-2010$ & $1900-2012$ \\
\hline 163 & Togo & $1996-2008$ & $1950-2008$ & $1916-2012$ \\
\hline 164 & Trinidad and Tobago & $1996-2008$ & $1950-2008$ & $1900-2012$ \\
\hline 165 & Tunisia & $1996-2010$ & $1958-2010$ & $1900-2012$ \\
\hline 166 & Turkey & $1996-2010$ & $1949-2010$ & $1900-2012$ \\
\hline 167 & Turkmenistan & $1996-2010$ & $1991-2010$ & $1990-2012$ \\
\hline 168 & Uganda & $1996-2010$ & $1953-2010$ & $1900-2012$ \\
\hline 169 & Ukraine & $1996-2010$ & $1990-2010$ & $1990-2012$ \\
\hline 170 & United Arab Emirates & $1996-2010$ & - & - \\
\hline 171 & United Kingdom & $1996-2010$ & $1900-2010$ & $1900-2012$ \\
\hline 172 & United States & $1996-2010$ & $1932-2010$ & $1900-2012$ \\
\hline 173 & Uruguay & $1996-2010$ & $1920-2010$ & $1900-2012$ \\
\hline 174 & Uzbekistan & $1996-2010$ & $1990-2010$ & $1990-2012$ \\
\hline 175 & Vanuatu & - & - & $1906-2012$ \\
\hline 176 & Venezuela & $1996-2010$ & $1929-2010$ & $1900-2012$ \\
\hline & Vietnam, Democratic & & & \\
\hline 177 & Republic of & - & - & $1945-2012$ \\
\hline 178 & Vietnam, Republic of & - & - & $1902-1975$ \\
\hline 179 & Yemen & $1996-2010$ & $1990-2010$ & $1918-2012$ \\
\hline 180 & Zambia & $1996-2010$ & $1950-2010$ & $1911-2012$ \\
\hline
\end{tabular}


Table A.6. The Effects of Democracy and Governance in Different Subsamples

\begin{tabular}{|c|c|c|c|c|c|}
\hline DV & $\begin{array}{c}(1) \\
1960-\end{array}$ & $\begin{array}{c}(2) \\
1946-\end{array}$ & $\begin{array}{c}(3) \\
1974- \\
\text { Mortality Ra }\end{array}$ & $\begin{array}{ll} & (4) \\
\text { g) } & \end{array}$ & $\begin{array}{c}(5) \\
1960-\end{array}$ \\
\hline Electoral Principle & $\begin{array}{c}-0.0485^{* * *} \\
{[0.00714]}\end{array}$ & $\begin{array}{c}-0.0394 * * * \\
{[0.00772]}\end{array}$ & $\begin{array}{c}-0.0652^{* * *} \\
{[0.00866]}\end{array}$ & & \\
\hline Legislative Constraints & & & & $\begin{array}{c}-0.0339 * * * \\
{[0.00505]}\end{array}$ & \\
\hline Polity & & & & & $\begin{array}{c}-0.00172 * * * \\
{[0.000216]}\end{array}$ \\
\hline No-Corruption Index & $\begin{array}{l}0.0204 * * \\
{[0.00767]}\end{array}$ & $\begin{array}{c}-0.0284 * * * \\
{[0.00816]}\end{array}$ & $\begin{array}{c}0.0493 * * * \\
{[0.00950]}\end{array}$ & $\begin{array}{c}0.0175^{*} \\
{[0.00747]}\end{array}$ & $\begin{array}{l}0.0248 * * \\
{[0.00785]}\end{array}$ \\
\hline GDP per capita, logged & $\begin{array}{c}-0.00378 \\
{[0.00325]}\end{array}$ & $\begin{array}{c}-0.0120^{* * *} \\
{[0.00363]}\end{array}$ & $\begin{array}{c}-0.00707 \\
{[0.00414]}\end{array}$ & $\begin{array}{l}-0.00430 \\
{[0.00321]}\end{array}$ & $\begin{array}{l}-0.00806^{*} \\
{[0.00333]}\end{array}$ \\
\hline Urbanization Rate & $\begin{array}{c}0.0478^{* *} \\
{[0.0174]}\end{array}$ & $\begin{array}{c}0.0177 \\
{[0.0179]}\end{array}$ & $\begin{array}{c}0.116^{* * *} \\
{[0.0262]}\end{array}$ & $\begin{array}{l}0.0419^{*} \\
{[0.0172]}\end{array}$ & $\begin{array}{c}0.0560^{* *} \\
{[0.0177]}\end{array}$ \\
\hline _cons & $\begin{array}{c}0.173^{* * *} \\
{[0.0356]}\end{array}$ & $\begin{array}{c}0.289 * * * \\
{[0.0405]}\end{array}$ & $\begin{array}{c}0.207 * * * \\
{[0.0450]}\end{array}$ & $\begin{array}{c}0.172^{* * *} \\
{[0.0352]}\end{array}$ & $\begin{array}{c}0.184^{* * *} \\
{[0.0367]}\end{array}$ \\
\hline Year FE & $\mathrm{V}$ & $\mathrm{V}$ & $\mathrm{V}$ & $\mathrm{V}$ & $\mathrm{V}$ \\
\hline Country FE & $\mathrm{v}$ & $\mathrm{v}$ & $\mathrm{v}$ & $\mathrm{v}$ & $\mathrm{v}$ \\
\hline Lagged DV & $\mathrm{v}$ & $\mathrm{V}$ & $\mathrm{V}$ & $\mathrm{v}$ & $\mathrm{V}$ \\
\hline $\mathrm{N}$ & 5855 & 6782 & 4485 & 5916 & 5605 \\
\hline adj. R-sq & 0.987 & 0.986 & 0.977 & 0.987 & 0.988 \\
\hline Countries & 146 & 146 & 145 & 146 & 143 \\
\hline Log Likelihood & 8487.4 & 8413.2 & 6576.3 & 8604.4 & 8196.3 \\
\hline
\end{tabular}

